WAPD-TM-146

AEC RESEARCH AND DEVELOPMENT REPORT

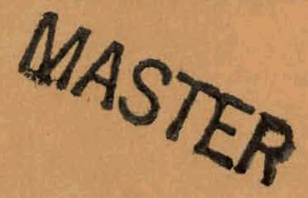

SN5001-AN IBM-650 CODE FOR STEADY-STATE THERMAL EVAL UATION OF AN INSTRUMENTED MULTI-FUEL- PLATE SUBASSEMBLY

APRIL 1960

CONTRACT AT-11-1-GEN-14

BETTIS ATOMIC POWER LABORATORY, PITTSBURGH, PA., OPERATED FOR THE U.S. ATOMIC ENERGY COMMISSION BY WESTINGHOUSE ELECTRIC CORPORATION 


\section{DISCLAIMER}

This report was prepared as an account of work sponsored by an agency of the United States Government. Neither the United States Government nor any agency Thereof, nor any of their employees, makes any warranty, express or implied, or assumes any legal liability or responsibility for the accuracy, completeness, or usefulness of any information, apparatus, product, or process disclosed, or represents that its use would not infringe privately owned rights. Reference herein to any specific commercial product, process, or service by trade name, trademark, manufacturer, or otherwise does not necessarily constitute or imply its endorsement, recommendation, or favoring by the United States Government or any agency thereof. The views and opinions of authors expressed herein do not necessarily state or reflect those of the United States Government or any agency thereof. 


\section{DISCLAIMER}

Portions of this document may be illegible in electronic image products. Images are produced from the best available original document. 
UC-34: Physics and Mathematics TID-4500 (15th Ed.).

\title{
SN5001-AN IBM-650 CODE FOR STEADY-STATE THERMAL EVALUATION OF AN INSTRUMENTED MULTI-FUEL-PLATE SUBASSEMBLY
}

E. Arbtin and R. B. Westphal

April 1960

Contract AT-11-1-GEN-14

Price $\$ \mathbf{0 . 7 5}$

Available from the Officc of Technical Services,

Department of Commerce,

Washington 25, D. C.

\section{NOTE}

This document is an interim memorandum prepared primarily for internal reference and does not represent a final expression of the opinion of Westinghouse. When this memorandum is distributed externally, it is with the express understanding that Westinghouse makes no representation as to completeness, accuracy, or usability of information contained therein.

\author{
BETTIS ATOMIC PÓWER LABORATORY \\ PITTSBURGH, PENNSYLVANIA


STANDARD EXTERNAL DISTRIBUTION

No. Copies

UC-34: Physics and Mathematics, TID-4500, 15th Edition

611

\section{SPECIAL EXTERNAL DISTRIBUTION}

Manager , Pittsburgh Naval Reactors Operations Office, AEC Newport News, A. P. Zechella

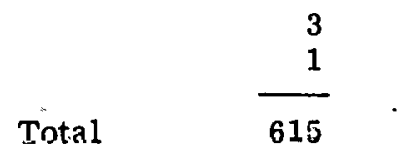

\section{LEGAL NOTICE}

This report was prepared as an account of Government sponsored work. Heither the United States, nor the Commission, nor any person acting on behalf of the Commission:

A. Makes any warranty or represcntation, expressed or implied, with respect to the accuracy, completeness, or usefulness of the information contained in this report., ar that the use of any information, apparatus, method, or process disclosed in this report may not infringe privately owned rights; or

B. Assumes any liabilities with respect to the use of, or for damages resulting from the use of any information, apparatus, method, or process disclosed in this report.

As used in the above, "person acling on behalf of the commission" includes any employe or contractor of the Commission, or employe of such contractor, to the extent that such employe or contractor of the Commission, or employe of such contractor prepares, disseminates, or provides access to, any information pursuant to his employment or contract with the Commission, or his employment with such contractor. 
Page No.

I. INTRODUCTION

II. CALCULATIONAL PROCEDURE

A. Terminology and Assumptions $\quad \cdot \quad 1$

Definitions and Symbols $\quad$ · 1

$\begin{array}{llll}\text { Subscripts } \quad-\quad & - & 3\end{array}$

Assumptions Used $\quad \cdot \quad \cdot \quad 4$

B. General Method

C. Calculational Procedure for a Slab when Coolant Is Subcooled or

Bulk Boiling and the Heat Transfer Surfaces Are in the Heating

or Local Boiling Region

Determination of $\mathrm{F}_{\mathrm{A}_{1}} \quad \ldots$

Determination of $\mathrm{T}_{\mathrm{tc}_{1}}$

D. Calculational Procedure for a Slab when One Heat Transfer
Surface of the Center Plate Is Film Boiling

III. DERIVATION AND LIST OF HEAT CONDUCTION EQUATIONS $\quad 6$

A. Sample Heat Conduction Equations for the End Plates (A or D) 7

B. Sample Heat Conduction Equations for the Center Fuel Plate $\quad 7$

C. Tabulation of Heat Conduction Equations $\quad$. 8

- $\mathrm{T}_{2}$ and $\mathrm{T}_{6}$ in Forced Convection $\quad 8$

$\mathrm{T}_{2}$ in Nucleate Boiling and $\mathrm{T}_{6}$ in Forced Convection . . 8

$\mathrm{T}_{2}$ in Forced Convection and $\mathrm{T}_{6}$ in Nucleate Boiling 9

$\mathrm{T}_{2}$ and $\mathrm{T}_{6}$ in Nucleate Boiling

$\mathrm{T}_{8}$ in Forced Convection (Hot Spot in B) 9

$\mathrm{T}_{8}$ in Nucleate Boiling (Hot Spot in B)

$\mathrm{T}_{15}$ in Forced Convection (Hot Spot in B) . 10

$T_{15}$ in Nucleate Bolling (Hot Spot in B) 10

$\mathrm{T}_{15}$ in Forced Convection (Hot Spot in C) 10

$T_{15}$ in Nucleate Boiling (Hot Spot in C) 10

$\mathrm{T}_{8}$ in Forced Convection (Hot Spot in C) .

$\mathrm{T}_{8}$ in Nucleate Bolling (Hot Spot in C) $\quad 11$

$\mathrm{T}_{17}$ and $\mathrm{T}_{21}$ in Forced Convection $\quad 11$

$\mathrm{T}_{17}$ in Nucleate Boiling and $\mathrm{T}_{21}$ in Forced Convection 11

$\mathrm{T}_{17}$ in Forced Convection and $\mathrm{T}_{21}$ in Nucleate Boiling 11

$\bar{T}_{17}$ and $\mathrm{T}_{21}$ in Nucleade Böling 12

IV. DERIVATION AND LIST OF COOLANT ENTHALPY EQUATIONS 12 
V. METHOD OF COMBINING THE EQUATIONS 13

VI. DESCRIPTION OF CODE $\quad 13$
A. Code Input

B. Code Output

C. Computer Operation

D. Code Subroutines

APPENDIX A: A NOTE ON THE ASSUMPTION OF SEPARABILITY OF VARIABLES · 20 ACKNÖWLEDGEMENTS $\quad 21$

REFERENCES 
This report describes an IBM-650 computer program, SN500I, for the colculation of steady. state thermal conditions in the fual plates and coolent of an instrumented multi-fuel-plate subassembly. The program is applicable for subcooled or bulk bolling coolont conditions and surface condifions of heating, local boiling, and film bolling, and can bo used for dafa reduction or design. The report includes the derivation and a list of the heat conduction and coolant enthalpy equations and a description of the code sufflelent for its use.

SN5001 - AN IBM-650 CODE FOR STEADY-STATE

THERMAL EVALUATION OF AN INSTRUMENTED

MULTI-FUEL-PLATE SUBASSEMBLY

E. Arbtin* and R. B. Westphal*

\section{INTRODUCTION}

An IBM-650 code has been written to perform steady-state thermal analyses of an instrumented multi-fuel-plate subassembly. The code can be used to analyze test data or predict thermal conditions in subassemblies in the design stage.

The code was written for the purpose of obtaining accurate steady-state fuel-plate temperatures, heat fluxes, coolant thermal conditions, and the normalized axial neutron distribution in the subassemblies from in-pile data. The heat split that occurs in the fuel plates, and the unequal heat fluxes on each side of a coolant channel (resulting from unequal fuel-p̀late loadings and coolant temperatures in the channels adjacent to the fuel plates) preclude an accurate, simple hand analysis and necessitate a digital computer analysis. The steady-state conditions described by the code include subcooled and bulk boiling coolant conditions, and heating, local boiling, and film bolling surface conditions. Subroutines were written to calculate surface temperatures for film boiling and for use in subassembly design using the axial neutron shape as input data instead of center plate measured temperatures.

*Naval Reactors. Facllity, Idaho Falls, Idaho.
The subassembly analyzed is a three-fuelplate, four-coolant channel core subdivision, designed for insertion in a water-moderated and water-cooled, pressurized, nuclear power reactor (see Fig. 1). The two end (outside) fuel plates are clad with non-fuel-bearing material. The center fuel plate is composed of two externally-clad heat generating sections, separated by a non-generating section in which thermocouples are imbedded.

Typical operating times have varied from approximately 15 to $20 \mathrm{~m}$ Inutes for non-boiling runs to runs with local bolling, for a 20-slab problem solving for either the axial neutron flux shape or the middle plates center temperature.

\section{CALCULATIONAL PROCEDURE}

A. Terminology and Assumptions

Definitions and Symbols

$A_{F}$ is the average cross-section area of the flow channel $\left(\mathrm{ft}^{2}\right)$.

$A_{s}$ is the heat transfer area $\left(\mathrm{ft}^{2}\right)$

BOLC is the code word that describes the heat transfer conditions on each surface. 


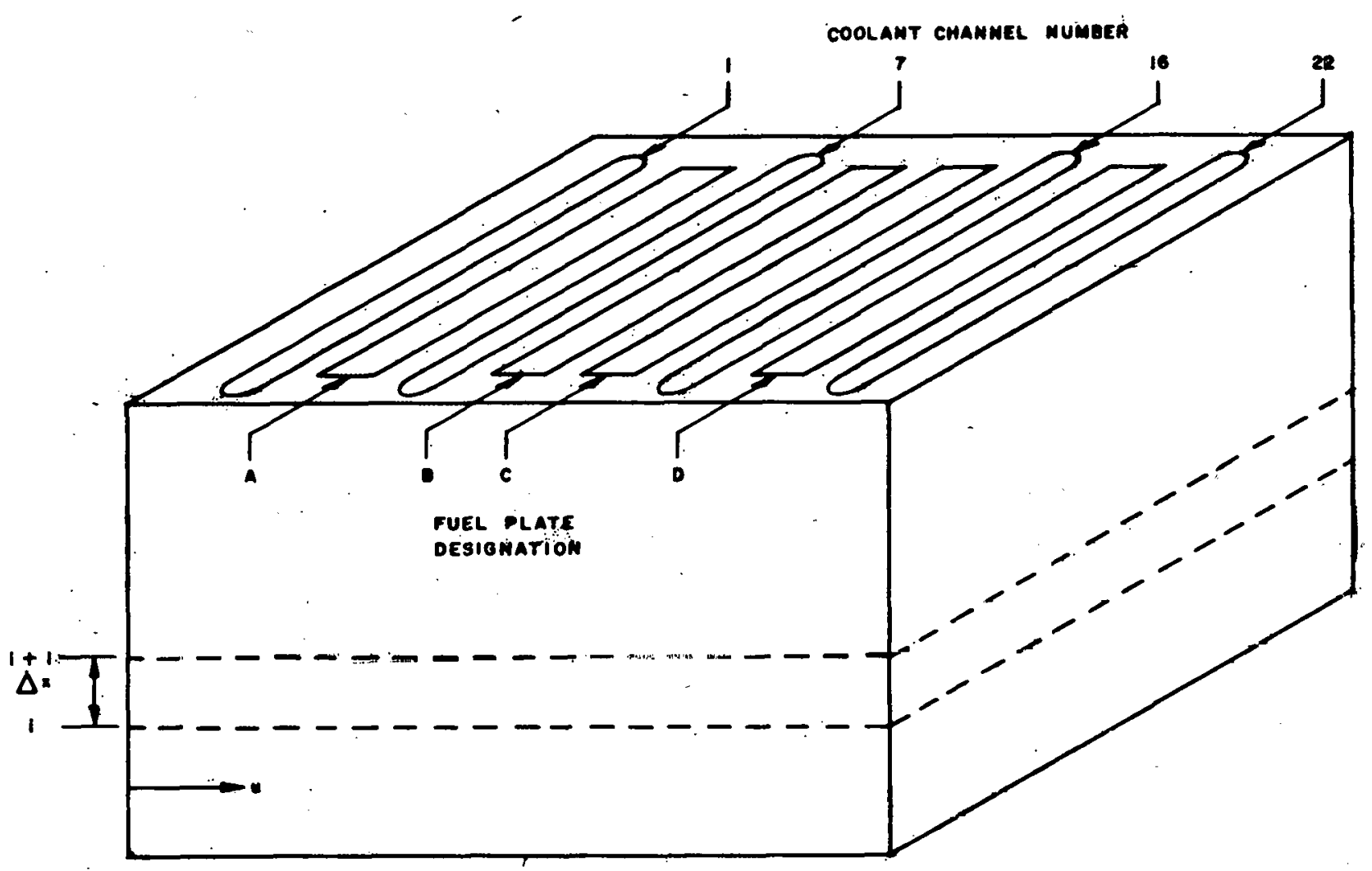

Fig. I Axial Section of Typical Instrumented Multifual Subassambly.

$\mathrm{D}_{e}$ 'is the coolant channel equivalent diameter (ft).

$F_{A_{i}}$ is the axial neutron flux factor in a given slab and is defined as the ratio of the average axial neutron flux in a given slab to the average axial neutron flux over the length of the subusuumbly meat (dinenslunless).

$F_{L_{u}}$ is the loading factor in a given slab and fuel plate, defined as the ratio of the local fuel density divided by the subassembly average fuel iensity (dimengionloov):

$F_{R_{u}}$ is the radial neutron flux factor and is defined as the ratio of the average radial neutron flux at each of the fuel locations to the average radial neutron flux. in the entire subassembly (dimensionless).

$\mathrm{G}_{\mathrm{u}}$ is the coolant mass velocity $\left(\mathrm{bb} / \mathrm{hr}-\mathrm{ft}^{2}\right)$.

$\mathrm{H}$ is enthalpy of the bulk coolant (Btu/lb).
$L$ is the total fuel length of the subassembly (ft).

$\mathrm{N}$ is the number of slabs.

$\mathrm{P}$ is the coolant channel power output $(\mathrm{Btu} / \mathrm{hr})$.

$Q$ is the total heat rate $(\mathrm{Btu} / \mathrm{hr})$ of the subassembly.

$T$ is the temperature $(\mathrm{F})$.

$T^{*}$ is the local boiling or film boiling surface temperatiure (" $F$ ).

$\bar{T}$ is the average coolant temperature in a slab channel ( $\left.{ }^{\circ} \mathrm{F}\right)$.

$\mathrm{T}_{\mathrm{s}}$ is the, local bolling surface temperature used in the ronde test: $0.02^{\circ} \mathrm{F}$.

$X$ is the location of the zero temperature gradient in a fuel section measured from the left-hand edge of the fuel (ft). 
$V_{m}$ is the total volume of the fuel $\left(\mathrm{ft}^{3}\right)$.

a, b, c, d, e, f, g, j, l, m, n, and $r$ are fuel and clad dimensions (ft). (See Fig. 2.)

$a_{1}$ is the constant in the Dittus-Boelter coefficient of heat transfer formula.

$c_{p}$ is the specific heat of the coolant at constant pressure (Btu/lb- $\left.{ }^{\circ} \mathrm{F}\right)$.

$\mathrm{h}$ is the coefficient of heat transfer (Btu/hr$\mathrm{ft}^{2}-{ }^{\circ} \mathrm{F}$ ).

$k$ is the thermal conductivity of the'clad and fuel material (Btu/hr-ft $\left.{ }^{2}-{ }^{\circ} \mathrm{F}-\mathrm{ft}\right)$.

$\mathrm{q}$ is heat flux (Btu/hr-ft ${ }^{2}$ ).

$\bar{q}^{\prime \prime \prime}$ is the average heat generation rate in the subassembly (Btu/hr- $\mathrm{ft}^{2}$ ).

$q_{i u}^{\prime \prime \prime}$ is the uniform heat generation rate in the $u^{\prime}$ th fuel section in the $i^{\prime}$ th slab (Btu/hr-ft ${ }^{3}$ ).

$t$ is the thickness dimension ( $\mathrm{ft}$ ).

$w$ is the width dimension (ft).
$\mathrm{H}_{\mathrm{u}}$ is the difference in enthalpy of the outlet and inlet coolant of a given channel (Btu/lb).

$x$ is the slab height (ft).

$\mu$ is the absolute viscosity of the coolant $(\mathrm{lb} /$ $\mathrm{hr}-\mathrm{ft}$ ).

$\lambda$ is the grouping of water properties used in the Dittus-Boelter . equation $\left(\mathrm{Btu} /{ }^{\circ} \mathrm{F}\right)(1 / \mathrm{lb})^{0.8}$ $(1 / \mathrm{ft}-\mathrm{hr})^{0.4}$.

$\epsilon$ is a tolerance placed on the location of the maximum temperature in fuel section $B$ or $C$ (ft). Used in code as $1 \times 10^{-7} \mathrm{ft}$.

Subscripts

A, B, C, and D designate the four fuel plates, respectively (see Fig.2).

c designates the coolant channel.

I designates the inlet.

1 designates a particular slab.

m designates the fuel.

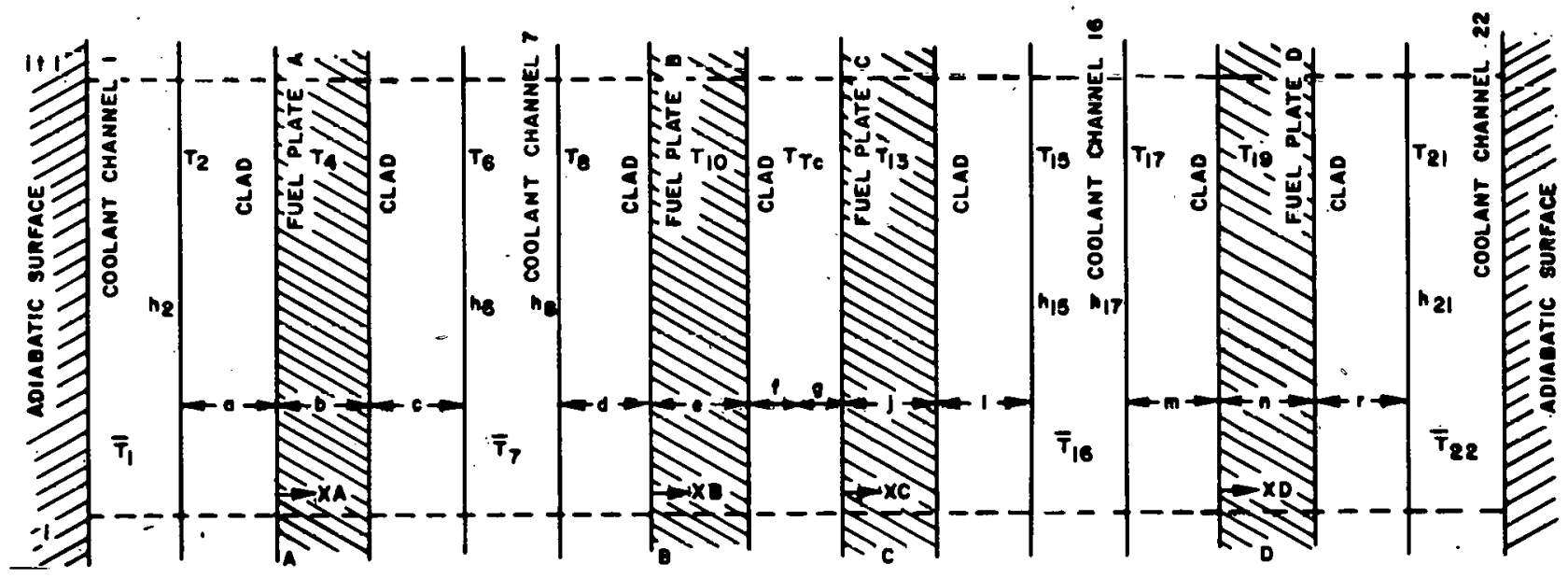

Fig. 2 side View of Subossembly Showing Nomenclofure 
O designates the outlet.

tc designates the center fuel-plate thermocouple temperature (see Fig. 2).

$u$ designates a particular coolant channel or fuel section in a slab.

Arabic numerals refer to locations in the sub-. assembly (see Fig. 2).

\section{Assumptions Used}

The following assumptions were used in derving the heat conduction and coolant enthalpy equations and the methods of solution:

1) Only one-dimensional heat flow, perpendicular to the heat transfer surface, can occur.

2) Uniform heat generation rate, $\mathrm{q}_{\mathrm{iu}}^{\prime \prime \prime}$ in Btu/ $\mathrm{hr}-\mathrm{ft}^{3}$, within each given fuel section of a given slab.

3) All of the heat output of the subassembly is generated in the fuel sections. This assumption speclfles that there is no heat generation in clad material or water.

4) The subassembly boundaries are adiabatic.

5) The axial neutron flux factor $\mathrm{F}_{\mathrm{A}_{\mathrm{i}}}$ is dependent on axial location and independent of radial location in the subassembly.

6) The radial neutron flux factor $F_{R_{u}}$ is a constant for a given fuel plate.

7) The local boiling surface temperature is a constant and holds until departure from nucleate bolling (DNB) occurs, and is independent of coolant quality and pressure. It is found by the Jens-Lottes formula (Ref 1).
8) The Dittus-Boelter heat transfer film coefficient formula is. correct in the subcooled nonboiling region, and is constant over small temperature changes.

Thus,

$$
h=a_{1}\left(\frac{D_{e} G}{u}\right)^{0.8}\left(\frac{c_{p} u}{k}\right)^{0.4} \frac{k}{D_{e}}
$$

and

$$
\mathrm{h}=\mathrm{a}_{1} \mathrm{G}^{0.8} \mathrm{D}_{\mathrm{e}}^{0.2} \lambda
$$

where $\lambda=\mathrm{k}^{0.6}\left(\frac{c_{\mathrm{p}}}{\mathrm{u}}\right)^{0.4}$.

9) The thermal conductivities of olad and fuel materials are equal and independent of temperature.

10) The specific heat of water is constant over small temperature changes.

11). The split finel sections of the center fuel plate are the same width at any axial location.

12) The average volumetric heat generution rate is the summation of the product of coolant enthalpy rise in the channels, the coolant mass flowrato, and the cliamel flow aren divided by tlie lulul volume of the heat generation material. Thus,

$$
\bar{q}^{\prime \prime \prime}=\frac{1}{V_{m}} \text { channel } \sum_{1}^{4} H_{u} G_{u} A_{F_{u}} \text {. }
$$

13) The local volumetric heat generation $r a t e$ is the product of the average volumetric heat generation rate, the loading factor, and the axial and radial neutron flux factors. Thus,

$$
\mathrm{q}_{\mathrm{iu}}^{\prime \prime \prime}=\overline{\mathrm{q}}^{\prime \prime \prime} \quad \mathrm{F}_{\mathrm{L}_{\mathrm{iu}}} \quad \mathrm{F}_{\mathrm{A}_{\mathrm{i}}} \quad \mathrm{F}_{\mathrm{R}_{\mathrm{u}}}
$$

\section{B. General Method}

The axial length of the subassembly is divided into not more than 99 slabs of equal or unequal 
length for calculational purposes. Calculations proceed from the inlet slab consecutively to the exit slab.

A set of equations (Sections III and IV) has been derived that completely describes the heat generation, heat transfer, and average bulk coolant conditions in a. slab of the subassembly ( $i$ to $i+1$ in Figs. 1 and 2). These equations are written as a function of the dimensions, fuel-plate volumetric heat generation rate, coolant channel mass velocities, the thick plate center temperature, and individual plate boundary conditions, i.e., water temperature and film coefficient or surface temperature. The equations were programmed to allow the most flexible use of the code. The calculation is made by solving the set of four simultaneous equations, that describe the thermal conditions in the coolant channels and fuel plates in a given slab, for the proper boundary conditions. Then, the next slab is indexed, using as inlet coolant conditions the exit conditions of the previous slab.

The method of calculation, as coded, permits the evaluation of either the normalized axial neutron flux factor $F_{A}$ or the center-plate center temperature $T_{t c}$ for each slab, by finding the solution to the set of simultaneous equations.

It is conoidored necessary and arvantageous in analyzing test data to solve for an axial neutron flux shape $F_{A}$ for each test'run, because neutron flux measurements are generally not made for all test runs, and because the flux measuring locations are such that they do not "see" all of the neutron depression in fuel plate sections that contain higher fuel loadings.

C. Calculational Procedure for a Slab when Coolant Is Subcooled or Bulk Bolling and the Heat Transfer Surfaces Are in the Heating or Local Bolling Region

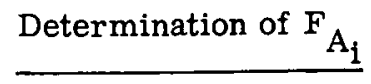

The procedure uses as input data: values of the constant $a_{1}$ in the Dittus-Boelter equation, thermocouple temperature $T_{t c}, F_{R}$ values for each fuel plate, thermal conductivity, mass velocities in each channel, and the average subassembly heat generation rate.

The $F_{A_{1}}$ in each slab is determined by the following procedure:

1) Assuming nonboiling conditions on all heat transfer surfaces, calculate the location $\left(X_{u^{\prime}}\right.$ 's) of the maximum temperatures in each fuel plate [Eqs (1a)* and (13a) for the outside fuel plates, $A$ and $D$, and Eqs (5a) and (7a) for the center fuel plate, assuming the maximum temperature of the center plate is in the $B$ fuel section].

2) Check the location of the maximum temperature in the center plate to see if it agrees with the assumptions.

3) If step 2 does not agree with step 1, then repeat step 1, using Eqs (9a) and (11a) in placc of Eqs (5a) and (7a), Assuming the maximum temperature of the center plate is in the $\mathrm{C}$ fuel section with no local boiling. (See Section III-C.) If surfaces are undergoing local boiling, use the, appropriate equations.

4) If step 2 does agree with step 1, go to step 5.

5) Compare all heat transfer surface temperatures with the local bolling surface temperature. (For ease in calculations, an average local bolling surface temperature according to coolant pressure is used for comparison.)

\footnotetext{
*See Sections III and IV for the listing of equations.
} 
6) If step 5 indicates that all of the heat.transfer surface temperatures are below the local boiling surface temperature, calculate and store the items listed in step 15 for that slab and repeat step 1 for the next slab.

7) If step 5 indicates that one or more heat transfer surfaces are local boiling, solve for the $\mathrm{X}_{\mathbf{u}}$ 's, using the appropriate boundary condition equations of Section III-C.

8) Repeat steps 2 through 5, as applicable.

9) If step 5 indicates that no additional heat transfer surfaces are local bolling, compute and store the items listed in step 15, and repeat step 1 for the next slab.

10) If step 5 indicates that additional heat transfer surfaces are local boiling, solve for the $\mathrm{X}_{\mathrm{u}}$ 's, using the appropriate boundary condition equations.

11) Repeat step 8.

12) Repeat step 9, if appröpriate.

13) Repeat step 10, if appropriate.

14) When the computation for all slabs has been completed, as determined by comparing the slab number to the total number of slabs in the subassembly, compute $F_{A_{a v e}}$ for the subassembly.

15) The following information for each slab will be recurded for furthcr use (determination of departure from nucleate. bolling heat flux, pressure drop, etc.): the location of the maximum temperature in each fuel plate, average and exit coolant temperature and enthalpy in each channel, fuel plate surface temperatures, and average heat flux on each heat transfér surface.
Determination of $T_{t c_{1}}$

The procedure is to solve for the slab conditions listed in steps 14 and 15 above by the method outlined in steps 1 to 13 , using $F_{A_{i}}$ as input to the code instead of $T_{t c_{i}}$, in addition to the other inputs listed.

D. Calculational Procedure for a Slab When One Heat Transfer Surface of the Center Plate Is Film Boiling

The film boiling heat transfer surface temperature $T_{R_{i}}^{*}$ on the left-hand surface of the center fuel plate $\left(\mathrm{T}_{8}\right.$ of Fig. 2) is found by solving the two equations (6a) and (8a), or (10a) and (12a) that describe the center plate simultaneously (see Section III-C). This calculation can be made for any slab in which film bolling is known or suspected. A special routine is required for this calculation. (See Section VI-D.)

$\mathrm{F}_{\mathrm{A}_{\mathrm{i}}}$ must be known for this calculation, in addition to the other input values listed in Section II-C. The opposite surface $\left(\mathrm{T}_{15}\right.$ of Fig. 2) is assumed to be undergoing local bolling.

The procedure for caloulating $F_{A_{1}}$ (3cc Section II-C) is uscd up to the slab in whlch fllm bolling is known or suspected; then a separate routine is used to solve for $T_{8_{1}}^{*}$ for that slab upon coded signal. Succeeding slabs may or may not use the procedure for film bolling surface temperature onloulntion.

\section{DERIVATION AND LIST OF HEAT CONDUC- TION EQUATIONS}

Equations were developed for each of the four fuel plates (A, B, C, and D of Figs. 1 and 2) that determined the location of the maximum temperatures in a fuel plate as a function of known or assumed conditions, 1.e., water temperature and film coefficient or surface temperature, ànd the 
heat generation rate. For the center split-meat plate, an additional boundary condition - the plate center temperature, was used.

The one-dimensional - Poisson equation, $\frac{d^{2} T}{d^{2}}=$ $-\frac{q^{\prime \prime \prime}}{k}$, was used in calculating the temperature distribution across the heat generating material (meat); and the LaPlace equation, $\frac{d^{2} T}{d^{2}}=0$, was used in calculating the temperature distribution across the non-heat generating material (clad). (See Ref 3.)

Because of the similarity of the equations, only two sample derivations are presented, one for the two end plates and one for the center split-meat plate. The dimensional symbols and numbering scheme used in the derivations are shown in Fig. 2.

\section{A. Sample Heat Conduction Equations for the End Plates (A or D).}

For the boundary conditions $\mathrm{T}_{1}$ and $\mathrm{T}_{6}^{*}$ at the local boiling temperature), the equations from the maximum metal temperature $T_{4}$ to $T_{1}$ and $T_{6}^{*}$ are

$$
T_{4}-\bar{T}_{1}=\frac{q_{A}^{\prime \prime \prime} x_{A}^{2}}{2 k}+\frac{q_{A}^{\prime \prime \prime} x_{A}^{a}}{k}+\frac{q_{A}^{\prime \prime \prime} x_{A}}{h_{2}}
$$

and

$$
\mathrm{T}_{4}-\mathrm{T}_{6}^{*}=\frac{\mathrm{q}_{A}^{\prime \prime \prime}\left(\mathrm{b}-\mathrm{x}_{\mathrm{A}}\right)^{2}}{2 \mathrm{k}}+\frac{\mathrm{q}_{A}^{\prime \prime \prime}\left(\mathrm{b}-\mathrm{x}_{\mathrm{A}}\right) \mathrm{c}}{\mathrm{k}} .
$$

By solving each equation for $\mathrm{T}_{4}$ and then setting the resultant equations equal to each other, the location of the maximum metal temperature $X_{A}$ is found to be

$$
x_{A}=\frac{T_{6}^{*}-\bar{T}_{1}}{q_{A}^{\prime \prime \prime}\left(\frac{a+b+c}{k}+\frac{1}{h_{2}}\right)}+\frac{\frac{\left(b^{2}+2 b c\right)}{2 k}}{\left(\frac{a+b+c}{k}+\frac{1}{h_{2}}\right)}(3 a)^{\dagger}
$$

TThe equation numbers given are from the Tabulation of Heat Conduction Equationg, Sention III-C.
Then, temperatures and plate surface heat fluxes can be found as a function of $q_{A}^{\prime \prime \prime}$, the boundary conditions, and $\mathrm{x}_{\mathrm{A}}$ as follows:

$$
\begin{gathered}
\mathrm{T}_{2}=\frac{\mathrm{q}_{A}^{\prime \prime \prime} \cdot \mathrm{x}_{A}}{\mathrm{~h}_{2}}+\overline{\mathrm{T}}_{1} \\
\mathrm{~T}_{4}=\frac{\mathrm{q}_{A}^{\prime \prime \prime} \mathrm{x}_{A}^{2}}{2 \mathrm{k}}+\frac{\mathrm{q}_{A}^{\prime \prime \prime} \mathrm{x}_{A}{ }^{\mathrm{a}}}{\mathrm{k}}+\mathrm{T}_{2} \\
\mathrm{q}_{2}=\mathrm{q}_{A}^{\prime \prime \prime} \mathrm{x}_{A} \\
-\mathrm{q}_{6}=\mathrm{q}_{A}^{\prime \prime \prime}\left(\mathrm{b}-\mathrm{x}_{A}\right)
\end{gathered}
$$

The method of derivation for the $\mathrm{A}$ and $\mathrm{D}$ fuel plates is similar; only the letter and number designations are different. Equations (1) through (4) in Section III-C of this report completely describe all of the possible boundary conditions for fuel plates $A$ and $D$.

B. Sample Heat Conduction Equation for the Center Fuel Plate

The equations derived for the center fuel plate utilize the three boundary conditions: coolant temperature and film coefficient - or surface temperature on each side of the plate, and the plate center temperature $T_{t c}$. Separate sets of equations, Eqs (5) through (8) and Eqs (9) through (12), are derived for the two possible locations of the maximum metal temperatures, plate $\mathrm{B}$ or $\mathrm{C}$, respectively. The procedure will be to assume that the maximum metal temperature is in one fuel section (assume B) and then solve for $X_{B}$, the location of the maximum temperature. If the solution for $X_{B}$ is in an impossible location $\left(0<\mathrm{x}_{\mathrm{B}}<\mathrm{e}\right)$, then the set of equations for the maximum metal temperature location in the other fuel section (C) will be used for that slab calculation.

One example for the boundary conditions of $\bar{T}_{7}$. $h_{8}, T_{t c}$, and $T_{15}^{*}$ (Fig. 2) and the assumed location of the maximum metal temperature, $\mathrm{T}_{10}$, in plate $B$ is given. The heat transfer equations are 


$$
T_{10}-\bar{T}_{7}=\frac{q_{B}^{\prime \prime \prime} x_{B}^{2}}{2 k}+\frac{q_{B}^{\prime \prime \prime} x_{B}^{d}}{k}+\frac{q_{B}^{\prime \prime \prime} x_{B}}{h_{8}}
$$

$$
T_{10}-T_{t c}=\frac{q_{B}^{\prime \prime \prime}\left(e-X_{B}\right)^{2}}{2 k}+\frac{q_{B}^{\prime \prime \prime}\left(e-X_{B}\right) f}{k}
$$

Solving each equation for $T_{10}$ and setting the resultant equations equal to each other, the location of the maximum metal temperature is found in terms of $\overline{\mathrm{T}}_{\mathrm{tc}}, \mathrm{T}_{7}$, and $\mathrm{q}_{\mathrm{B}}^{\prime \prime \prime}$ : Thus,

$$
x_{B}=\frac{T_{t c}-\bar{T}_{q}}{q_{B}^{\prime \prime \prime}\left(\frac{d+e+f}{k}+\frac{1}{h_{8}}\right)}+\frac{\left(\frac{e^{2}}{2 k}+\frac{e f}{k}\right)}{\left(\frac{d+e+f}{k}+\frac{1}{h_{8}}\right)} \cdot \text {. (5a) }
$$

Solving from $T_{\text {tc }}$ to $T_{15}$ gives

$T_{t c}-T_{15}^{*}=q_{B}^{\prime \prime \prime} \frac{\left(e-X_{B}\right)(g+j+1)}{k}+\frac{q_{c}^{\prime \prime \prime} j^{2}}{2 k}+\frac{q_{c}^{\prime \prime \prime} j 1}{k}$

and

$$
x_{B}=-\frac{T_{t c}-T_{15}^{*}}{q_{B}^{\prime \prime \prime}\left(\frac{g+j+1}{k}\right)}+\frac{q_{c}^{\prime \prime \prime} j\left(\frac{j+21}{2 k}\right)}{q_{B}^{\prime \prime \prime}\left(\frac{g+j+1}{k}\right)}+e .
$$

Then, temperatures and plate surface heat fluxes can be found as a function of the heat generation rates, the boundary conditions, and $x_{B}$ as follows:

$$
\begin{gathered}
\mathrm{T}_{8}=\frac{\mathrm{q}_{B}^{\prime \prime} \mathrm{x}_{\mathrm{B}}}{\mathrm{h}_{8}}+\overline{\mathrm{T}}_{7} \\
\mathrm{~T}_{10}=\frac{\mathrm{q}_{B}^{\prime \prime \prime} \mathrm{x}_{\mathrm{B}}^{2}}{2 \mathrm{k}}+\frac{\mathrm{q}_{B}^{\prime \prime \prime} \mathrm{x}_{B}{ }^{\mathrm{d}}}{\mathrm{k}}+\mathrm{T}_{8} \\
\mathrm{q}_{8}=\mathrm{q}_{B}^{\prime \prime \prime} \mathrm{x}_{B} \\
\mathrm{q}_{15}=\mathrm{q}_{B}^{\prime \prime \prime}\left(e-\mathrm{x}_{B}\right)+q_{c}^{\prime \prime \prime} j
\end{gathered}
$$

Equations (5) to (12) of Section III-C completely describe all possible boundary conditions for the center fuel plate.
C. Tabulation of Heat Conduction Equations $\mathrm{T}_{2}$ and $\mathrm{T}_{6}$ in Forced Convection ${ }^{\dagger}$

$$
x_{A}=\frac{\bar{T}_{7}-\bar{T}_{I}}{q_{A}^{\prime \prime \prime}\left(\frac{a+b+c}{k}+\frac{1}{h_{2}}+\frac{1}{h_{6}}\right)}
$$

$$
\begin{aligned}
& +\frac{1}{\left(\frac{a+b+c}{k}+\frac{1}{h_{2}}+\frac{1}{h_{6}}\right)}\left(\frac{b^{2}+2 b c}{2 k}+\frac{b}{h_{6}}\right)(1 a) \\
& T_{2}=\frac{q_{A}^{\prime \prime \prime} x_{A}^{\prime}}{h_{2}}+\bar{T}_{1} \\
& T_{6}=\frac{q_{A}^{\prime \prime \prime}\left(b-x_{A}\right)}{h_{6}}+\bar{T}_{7}
\end{aligned}
$$

$$
\begin{aligned}
& \mathrm{T}_{4}=\left(\frac{\mathrm{q}_{A}^{\prime \prime \prime}}{2 \mathrm{k}}\right) \mathrm{x}_{\mathrm{A}}^{2}+\left(\frac{\mathrm{q}_{A}^{\prime \prime \prime}}{\mathrm{k}}\right) \mathrm{x}_{\mathrm{A}} \mathrm{a}+\mathrm{T}_{2} \\
& \mathrm{q}_{3}=\mathrm{q}_{\mathrm{A}}^{\prime \prime \prime} \mathrm{x}_{\Lambda}
\end{aligned}
$$

$$
q_{6}=q_{A}^{\prime \prime \prime}\left(b-X_{A}\right)
$$

$\underline{T_{2}}$ in Nucleate Boiling and $T_{6}$ in Forced Convection

$$
\begin{aligned}
x_{A}= & \frac{\bar{T}_{7}-T_{2}^{*}}{q_{A}^{\prime \prime \prime}\left(\frac{a+b+c}{k}+\frac{1}{h_{6}}\right)} \\
& +\frac{1}{\left(\frac{a+b+c}{k}+\frac{1}{h_{6}}\right)}\left(\frac{b^{2}+2 b c}{2 k}+\frac{b}{h_{6}}\right)
\end{aligned}
$$

$$
\mathrm{T}_{2}=\mathrm{T}_{2}^{*}
$$$$
\mathrm{T}_{6}=\frac{\mathrm{q}_{\mathrm{A}}^{\prime \prime \prime}\left(\mathrm{b}-\mathrm{x}_{\mathrm{A}}\right)}{\mathrm{h}_{6}}+\overline{\mathrm{T}}_{7}
$$

$$
\mathrm{T}_{4}=\frac{\mathrm{q}_{\mathrm{A}}^{\prime \prime \prime}}{2 \mathrm{k}} \mathrm{x}_{\mathrm{A}}^{2}+\left(\frac{\mathrm{q}_{\mathrm{A}}^{\prime \prime \prime}}{\mathrm{k}}\right) \mathrm{x}_{\mathrm{A}} \mathrm{a}+\mathrm{T}_{2}
$$

\footnotetext{
See Fig. 2
} 


$$
\begin{aligned}
& q_{2}=q_{A}^{\prime \prime \prime} x_{A} \\
& q_{6}=q_{A}^{\prime \prime \prime}\left(b-x_{A}\right)
\end{aligned}
$$

$\mathrm{T}_{2}$ in Forced Convection and $\mathrm{T}_{6}$ in Nucleate Bolling

$\mathrm{x}_{A}^{\prime}=\frac{\mathrm{T}_{6}^{*}-\overline{\mathrm{T}}_{1}}{\mathrm{q}_{\mathrm{A}}^{\prime \prime \prime}\left(\frac{\mathrm{a}+\mathrm{b}+\mathrm{c}}{\mathrm{k}}+\frac{1}{\mathrm{~h}_{2}}\right)}$

$$
+\frac{1}{\left(\frac{a+b+c}{k}+\frac{1}{h_{2}}\right)}\left(\frac{b^{2}+2 b c}{2 k}\right)
$$$$
\mathrm{T}_{2}=\frac{\mathrm{q}_{\mathrm{A}}^{\prime \prime \prime} \mathrm{x}_{\mathrm{A}}}{\mathrm{h}_{2}}+\overline{\mathrm{T}}_{1}
$$$$
\mathrm{T}_{6}=\mathrm{T}_{6}^{*}
$$$$
T_{4}=\left(\frac{q_{A}^{\prime \prime \prime}}{2 k}\right) x_{A}^{2}+\left(\frac{q_{A}^{\prime \prime \prime}}{k}\right) x_{A} a+T_{2}
$$

$q_{2}=q_{A}^{\prime \prime \prime} x_{A}$

$q_{6}=q_{A}^{\prime \prime \prime}\left(b-x_{A}\right)$

$\mathrm{T}_{2}$ and $\mathrm{T}_{6}$ in Nucleate Boiling

$x_{A}=\frac{T_{6}^{*}-T_{2}^{*}}{q_{A}^{\prime \prime \prime}\left(\frac{a+b+c}{k}\right)}+\frac{1}{\left(\frac{a ! b 10}{k}\right)}\left(\frac{b^{2}+2 b c}{2 k}\right)$

$$
\mathrm{T}_{2}=\mathrm{T}_{2}^{*}
$$

$$
\mathrm{T}_{6}=\mathrm{T}_{6}^{*}
$$

$\mathrm{T}_{4}=\left(\frac{\mathrm{q}_{\mathrm{A}}^{\prime \prime \prime}}{2 \mathrm{k}}\right) \mathrm{x}_{\mathrm{A}}^{2}+\left(\frac{\mathrm{q}_{\mathrm{A}}^{\prime \prime \prime}}{\mathrm{k}}\right) \mathrm{x}_{\mathrm{A}} \mathrm{a}+\mathrm{T}_{2}$

$q_{2}=q_{A}^{\prime \prime \prime} X_{A}$

$q_{6}=q_{A}^{\prime \prime \prime}\left(b-x_{A}\right)$

$$
X_{B}=\frac{T_{t c}-\bar{T}_{7}}{q_{B}^{\prime \prime \prime}\left(\frac{d+e+f}{k}+\frac{l}{h_{8}}\right)}
$$

$$
+\frac{1}{\left(\frac{d+e+f}{k}+\frac{1}{h_{8}}\right)}\left(\frac{e^{2}}{2 k}+\frac{e f}{k}\right)
$$

where $0<\dot{X}_{B} \leq e$

$$
\mathrm{T}_{8}=\frac{\mathrm{q}_{\mathrm{B}}^{\prime \prime \prime} \mathrm{x}_{\mathrm{B}}}{\mathrm{h}_{8}}+\overline{\mathrm{T}}_{7}
$$

$$
T_{10}=\left(\frac{q_{B}^{\prime \prime \prime}}{2 k}\right) x_{B}^{2}+\left(\frac{q_{B}^{\prime \prime \prime}}{k}\right) x_{B}^{d}+T_{8}^{\prime}
$$

$q_{8}=q_{B}^{\prime \prime \prime} x_{B}$

$q_{15}=q_{B}^{\prime \prime \prime}\left(e-x_{B}\right)+q_{C}^{\prime \prime} j$

$\mathrm{T}_{8}$ in Nucleate Boiling (Hot Spot in B)

$X_{B}=\frac{T_{t c}-T_{8}^{*}}{q_{B}^{\prime \prime}\left(\frac{d+e+f}{k}\right)}+\frac{1}{\left(\frac{d+e+f}{k}\right)}\left(\frac{e^{2}}{2 k}+\frac{e f}{k}\right)$,

where $0<\mathrm{x}_{\mathrm{B}} \leq \mathrm{e}$

$\mathrm{T}_{8}=\mathrm{T}_{8}^{*}$

$\mathrm{T}_{10}=\left(\frac{\mathrm{q}_{\mathrm{B}}^{\prime \prime \prime}}{2 \mathrm{k}}\right) \mathrm{x}_{\mathrm{B}}^{2}+\left(\frac{\mathrm{q}_{\mathrm{B}}^{\prime \prime \prime}}{\mathrm{k}}\right) \mathrm{x}_{\mathrm{B}}^{\mathrm{d}}+\mathrm{T}_{8}$

$\mathrm{q}_{8}=\mathrm{q}_{\mathrm{B}}^{\prime \prime \prime} \mathrm{X}_{\mathrm{B}}$

$q_{15}=q_{D}^{\prime \prime \prime}\left(e-X_{B}\right)+q_{C}^{\prime \prime \prime} j$ 


$$
\begin{array}{r}
x_{B=} q_{B}^{\prime \prime \prime} \frac{T_{t c}-\bar{T}_{16}}{\left(\frac{g+j+l}{k}+\frac{1}{h_{15}}\right)}+q_{B}^{\prime \prime \prime}\left(\frac{g+j+l}{k}+\frac{1}{h_{15}}\right) \\
\cdot\left[q_{C}^{\prime \prime}{ }^{\prime j}\left(\frac{j+2 l}{2 k}+\frac{1}{h_{15}}\right)\right]+e, \quad(7 a)
\end{array}
$$

where $0<\mathrm{x}_{\mathrm{b}} \leq \mathrm{e}$

$\mathrm{T}_{16}=\frac{\mathrm{q}_{\mathrm{B}}^{\prime \prime \prime}\left(e-\mathrm{x}_{\mathrm{B}}\right)}{\mathrm{l}_{15}}+\frac{\mathrm{q}_{\mathrm{C}}^{\prime \prime} \mathrm{j}}{\mathrm{h}_{16}}+\overline{\mathrm{T}}_{\mathrm{ib}}$

$q_{8}=q_{B}^{\prime \prime \prime} x_{B}$

$q_{15}=q_{B}^{\prime \prime \prime}\left(e-x_{B}\right)+q_{C}^{\prime \prime} j$

$\mathrm{T}_{15}$ in Nucleate Boiling (Hot Spot in B)

$$
\begin{aligned}
x_{B}= & \frac{T_{t c}-T_{15}^{*}}{q_{B}^{\prime \prime \prime}\left(\frac{g+j+l}{k}\right)} \\
& +\frac{1}{q_{B}^{\prime \prime \prime}\left(\frac{g+j+l}{k}\right)}\left[q_{C}^{\prime \prime \prime} j\left(\frac{j+2 l}{2 k}\right)\right]+e,
\end{aligned}
$$

where $\mathrm{c}<\mathrm{x}_{\mathrm{B}} \leq \mathrm{e}$

$$
\begin{aligned}
& T_{8}=\frac{q_{B}^{\prime \prime \prime} x_{B}}{h_{8}}+\bar{T}_{7} \\
& T_{10}=\frac{q_{B}^{\prime \prime \prime} x_{B}^{2}}{2 k}+\frac{q_{B}^{\prime \prime} x_{B}^{d}}{k}+T_{8} \\
& T_{15}=T_{15}^{*} \\
& q_{8}=q_{B}^{\prime \prime \prime} x_{B} \\
& q_{15}-q_{B}^{\prime \prime \prime}\left(e-x_{B}\right)+q_{C}^{\prime \prime} j
\end{aligned}
$$

$x_{C}=\frac{T_{t c}-\bar{T}_{16}}{q_{C}^{\prime \prime \prime}\left(\frac{g+j+l}{k}+\frac{1}{h_{15}}\right)}+\frac{\left(\frac{j^{2}}{2 k}+\frac{j l}{k}+\frac{j}{h_{15}}\right)}{\left(\frac{g+j+l}{k}+\frac{1}{h_{15}}\right)}$

where $0 \leq \mathrm{x}_{\mathrm{C}}<\mathrm{j}$

$$
\begin{aligned}
T_{13}=\frac{q_{C}^{\prime \prime \prime}\left(j-x_{C}\right)^{2}}{2 k} & +\frac{q_{C}^{\prime \prime \prime}\left(j-x_{C}\right) \ell}{k} \\
& +\frac{q_{C}^{\prime \prime}\left(j-x_{C}\right)}{h_{15}}+\bar{T}_{16}
\end{aligned}
$$

$\mathrm{T}_{15}=\frac{\mathrm{q}_{\mathrm{C}}^{\prime \prime}\left(\mathrm{j}-\mathrm{x}_{\mathrm{C}}\right)}{\mathrm{h}_{15}}+\overline{\mathrm{T}}_{16}$

$q_{8}=q_{C}^{\prime \prime \prime} X_{C}+q_{B}^{\prime \prime \prime} e$

$\mathrm{q}_{15}=\mathrm{q}_{\mathrm{C}}^{\prime \prime}\left(\mathrm{j}-\mathrm{x}_{\mathrm{C}}\right)$

$\mathrm{T}_{15}$ in Nucleate Boiling (Hot Spot in C)

$$
x_{C}=\frac{i_{t c}-T_{15}^{*}}{q_{C}^{\prime \prime \prime}\left(\frac{g+j+\ell}{k}\right)}+\frac{\left(\frac{j^{2}}{2 k}+\frac{j l}{k}\right)}{\left(\frac{g+j+l}{k}\right)}
$$

where $0 \leq \mathrm{x}_{\mathrm{C}}<\mathrm{j}$

$T_{13}=\frac{q_{C}^{\prime \prime \prime}\left(j-x_{C}\right)^{2}}{2 k}+\frac{q_{C}^{\prime \prime \prime}\left(j-x_{C}\right)}{k}+T_{15}$

$\mathrm{T}_{15}=\mathrm{T}_{16}^{*}$

$q_{\dot{8}}=q_{C}^{\prime \prime \prime} X_{C}+\ddot{q}_{B}^{\prime \prime \prime} e$

$\mathrm{q}_{15}=q_{\mathrm{C}}^{\prime} \cdot\left(j-\mathrm{x}_{\mathrm{C}}\right)$

$\mathrm{T}_{8}$ in Forced Convection (Hot Spot in C)

$\mathrm{X}_{\mathrm{C}}=\frac{\overline{\mathrm{T}}_{\mathrm{tc}}-\overline{\mathrm{T}}_{7}}{q_{C}^{\prime \prime \prime}\left(\frac{\mathrm{f}+\mathrm{e}+\mathrm{d}}{\mathrm{k}}+\frac{1}{\mathrm{~h}_{8}}\right)}-\frac{q_{\mathrm{B}}^{\prime \prime \prime}\left(\frac{\mathrm{e}+2 \mathrm{~d}}{2 \mathrm{k}}+\frac{1}{\mathrm{~h}_{8}}\right)}{q_{C}^{\prime \prime \prime}\left(\frac{\mathrm{f}+\mathrm{e}+\mathrm{d}}{\mathrm{k}}+\frac{1}{\mathrm{~h}_{8}}\right)}$, 
where $0 \leq \mathrm{x}_{\mathrm{C}}<\mathrm{j}$

$$
T_{8}=\bar{T}_{7}+\frac{q_{B}^{\prime \prime \prime} \cdot e}{h_{8}}+\frac{q_{C}^{\prime \prime \prime} x_{C}}{h_{8}}
$$

$q_{8}{ }^{\prime \prime}=q_{C}^{\prime \prime \prime} x_{C}+q_{B}^{\prime \prime \prime} e$

$\mathrm{q}_{15}=\mathrm{q}_{\mathrm{C}}^{\prime \prime \prime}\left(\mathrm{j}-\mathrm{x}_{\mathrm{C}}\right)$

$\mathrm{T}_{8}$ in Nucleate Boiling (Hot Spot in C)

$x_{C}=\frac{T_{t c}-T_{8}^{*}}{q_{C}^{\prime \prime \prime}\left(\frac{f+e+d}{k}\right)}-\frac{q_{B}^{\prime \prime \prime} e\left(\frac{e+2 d}{2 k}\right)}{q_{C}^{\prime \prime \prime}\left(\frac{f+e+d}{k}\right)}$,

where $0 \leq \mathrm{x}_{\mathrm{C}}<\mathrm{j}$

$$
\begin{aligned}
& T_{8}=T_{8}^{*} \\
& q_{8}=q_{C}^{\prime \prime \prime} x_{C}+q_{B}^{\prime \prime \prime} e \\
& \dot{q}_{15}=q_{C}^{\prime \prime \prime}\left(j-x_{C}\right)
\end{aligned}
$$

$\mathrm{T}_{17}$ and $\mathrm{T}_{21}$ in Forced Convection

$$
\begin{aligned}
x_{D}= & \frac{\bar{T}_{22}-\bar{T}_{16}}{q_{D}^{\prime \prime \prime}\left(\frac{m+n+r}{k}+\frac{1}{h_{17}}+\frac{1}{l_{21}}\right)} \\
& +\frac{1}{\left(\frac{m+n+r}{k}+\frac{1}{h_{17}}+\frac{1}{h_{21}}\right)}\left(\frac{n^{2}+2 n r}{2 k}+\frac{n}{h_{21}}\right) \\
T_{17}= & \frac{q_{D}^{\prime \prime \prime} x_{D}}{h_{17}}+\bar{T}_{16} \\
T_{21}= & \frac{q_{D}^{\prime \prime \prime}\left(n-x_{D}\right)}{h_{c^{\prime} 1}}+\bar{T}_{22} \\
T_{19}= & \frac{q_{D}^{\prime \prime \prime} x_{D}^{2}}{2 k}+\frac{q_{D}^{\prime \prime \prime} x_{D}^{m}}{k}+T_{17} \\
q_{17}= & q_{D}^{\prime \prime \prime} x_{D} \\
q_{21}= & q_{D}^{\prime \prime \prime}\left(n-x_{D}\right)
\end{aligned}
$$

$\mathrm{T}_{17}$ in Nucleate Boiling and $\mathrm{T}_{21}$ in Forced convection

$$
\begin{aligned}
& x_{D}=\frac{\bar{T}_{22}-T_{17}^{*}}{q_{D}^{\prime \prime \prime}\left(\frac{m+n+r}{k}+\frac{1}{h_{21}}\right)} \\
&+\frac{1}{\left(\frac{m+n+r}{k}+\frac{1}{h_{21}}\right)}\left(\frac{n^{2}+2 n r}{2 k}+\frac{n}{h_{21}}\right) \\
& T_{17}=T_{17}^{*} \\
& T_{21}=\frac{q_{D}^{\prime \prime \prime}\left(n-x_{D}\right)}{h_{21}}+\bar{T}_{22} \\
&- T_{19}=\frac{q_{D}^{\prime \prime \prime} x_{D}^{2}}{2 k}+\frac{q_{D}^{\prime \prime \prime} x_{D}^{m}}{k}+T_{17} \\
& q_{17}=q_{D}^{\prime \prime \prime} x_{D} \\
& q_{21}=q_{D}^{\prime \prime \prime}\left(n-x_{D}\right)
\end{aligned}
$$

$\mathrm{T}_{17}$ in Forced Convection and $\mathrm{T}_{21}$ in Nucleate Boiling

$$
\begin{aligned}
X_{D}= & \frac{T_{\dot{2} 1}^{*}-\bar{T}_{16}}{q_{D}^{\prime \prime \prime}\left(\frac{m+n+r}{k}+\frac{1}{h_{17}}\right)} \cdot \\
& \frac{1}{\left(\frac{m+n+r}{k^{\prime}}+\frac{1}{h_{17}}\right)}\left(\frac{n^{2}+2 n r}{2 k}\right)
\end{aligned}
$$

$\mathrm{T}_{17}=\frac{\mathrm{q}_{\mathrm{D}}^{\prime \prime \prime} \mathrm{X}_{\mathrm{D}}}{\mathrm{h}_{17}}+\overline{\mathrm{T}}_{16}$

$\mathrm{T}_{21}=\mathrm{T}_{21}^{*}$

$T_{19}=\frac{q_{D}^{\prime \prime \prime} x_{D}^{2}}{2 k}+\frac{q_{D}^{\prime \prime \prime} x_{D}^{m}}{k}+T_{17}$

$q_{17}=q_{D}^{\prime \prime \prime} x_{D}$

$q_{21}=q_{D}^{\prime \prime \prime}\left(n-x_{D}\right)$ 
$\mathrm{T}_{17}$ and $\mathrm{T}_{21}$ in Nucleate Boiling

$X_{D}=\frac{T_{21}^{*}-T_{17}^{*}}{q_{D}^{\prime \prime \prime}\left(\frac{m+n+r}{k}\right)}+\frac{1}{\left(\frac{m+n+r}{k}\right)}\left(\frac{n^{2}+2 n r}{2 k}\right)$

$\mathrm{T}_{17}=\mathrm{T}_{17}^{*}$

$\mathrm{T}_{21}=\mathrm{T}_{21}^{*}$

$T_{19}=\frac{q_{D}^{\prime \prime \prime} x_{D}^{2}}{2 k}+\frac{q_{D}^{\prime \prime \prime} X_{D} m}{k}+T_{1 i}(16 d)$

$q_{17}=q_{D}^{\prime \prime \prime} x_{D}$

$q_{21} \quad q_{D}^{\prime \prime \prime}\left(n-X_{D}\right)$

\section{IV: DERIVATION AND LIST OF COOLANT ENTHALPY EQUATIONS}

The change in enthalpy of the coolant in a channel and slab is directly proportional to the heat input from the fuel plates and is inversely proportional to the coolant flowrate in the channel. Thus,

$$
H_{l u}=\frac{Q_{i u}}{{ }_{i_{u} A_{F u}}}
$$

where

$\mathrm{H}_{\mathrm{iu}}$ is the change in enthalpy in a given slab $\mathrm{i}$ and channel $u$.

$Q_{\mathrm{iu}}$ is the total heat rate into channel $u$ in slab $i$ and is equal to $\sum \mathrm{q}_{\mathrm{iu}}{ }^{\mathrm{A}} \mathrm{s}_{\mathrm{iu}}$.

$\mathrm{q}_{\mathrm{iu}}$ is the heat flux into the channel $\mathrm{u}$ in slab $\mathrm{i}$ from fuel plate $u$ in slab $i$.

${ }^{A} S_{i u}$ is the heat transfer area of fuel plate $u$ in slab $i$ and is equal to $\left(w_{m_{j}}\right)\left(x_{i}\right)$. (See Fig. 3.)

$G_{u}$ is the coolant mass velocity in channel $u$.

$A_{F}$ iu is the coolant flow area in channel $u$ in slab $i$ and is equal to $\left(w_{c_{i u}}\right)\left(t_{c_{i u}}\right)$. (See Fig. 3.)

Then, $\quad \mathrm{H}_{\mathrm{iu}}=\frac{\sum \mathrm{q}_{\mathrm{iu}} \mathrm{A}_{\mathrm{s}_{\mathrm{iu}}}}{\mathrm{G}_{\mathrm{u}} \mathrm{A}_{\mathrm{Fu}}}$

and $\quad \mathrm{H}_{\mathrm{iu}}=\frac{\sum \mathrm{q}_{\mathrm{iu}} \mathrm{w}_{\mathrm{iu}} \Delta \mathrm{x}_{1}}{\mathrm{G}_{\mathrm{u}} \mathrm{w}_{\mathrm{c}_{\mathrm{iu}}} \mathrm{t}_{\mathrm{c}_{\mathrm{iu}}}}$.

The enthalpy at the downstream edge of slab $i$, channel $u$, is $H_{i+1, u}=\Delta H_{i, u}+I I_{i, u}$ or
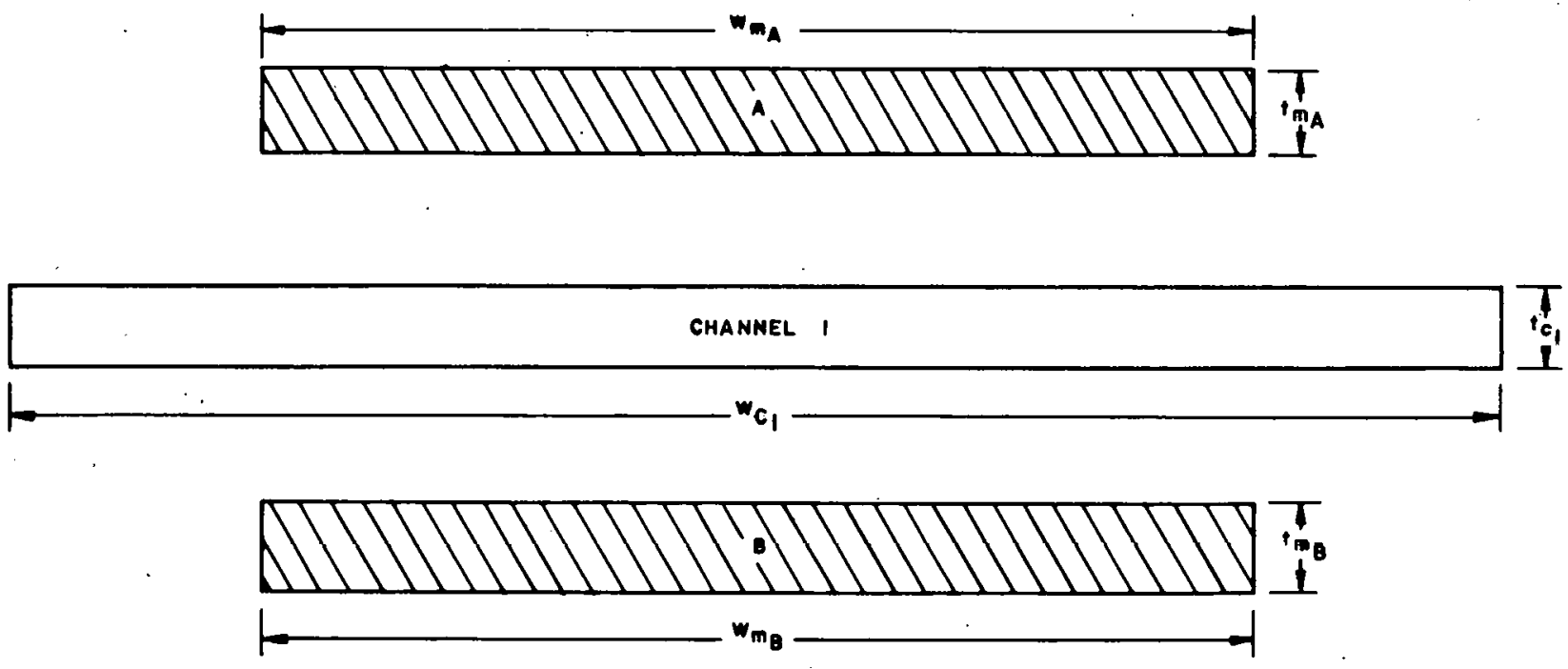

Fig. 3 Partiol Top Viow of Subassombly Showing Chonnel and Fuel Plate Nomenclature 
The average enthalpy in slab $i$, channel $u$, is then

$$
\overline{\mathrm{H}}_{\mathrm{iu}}=0.5 \Delta \mathrm{H}_{\mathrm{iu}}+\mathrm{H}_{\mathrm{I}_{\mathrm{iu}}}-
$$

It is necessary to have the average enthalpy equations converted to average temperature equations for use with the heat conduction equations in the subcooled region. This is accomplished by dividing the enthalpy rise by the specific heat of water and converting the inlet enthalpy to temperature by formula. Because the specific heat does not vary greatly over small $\Delta T$ 's, the $C_{p}$ corresponding to $\mathrm{H}_{\mathrm{iu}}$ will be used; therefore,

$$
\overline{\mathrm{T}}_{\mathrm{iu}}=0.5\left(\frac{\Delta \mathrm{H}_{\mathrm{iu}}}{\mathrm{Cp}_{\mathrm{iu}}}\right)+\mathrm{T}_{\mathrm{I}_{\mathrm{iu}}} .
$$

Combining terms,

$$
\overline{\mathrm{T}}_{i u}=\frac{0.5 \sum \mathrm{q}_{i u} \mathrm{w}_{\mathrm{m}_{\mathrm{iu}}} \Delta \mathrm{x}_{\mathrm{i}}}{\mathrm{Cp}_{\mathrm{iu}} \mathrm{G}_{\mathrm{u}} \mathrm{w}_{\mathrm{c}_{\mathrm{iu}}} \mathrm{t}_{\mathrm{c}_{\mathrm{iu}}}}+\mathrm{T}_{\mathrm{I}_{\mathrm{iu}}} .
$$

The following equations describe the average water temperature in a given slab i for each channel $u$ as a function of dimensions, water properties, channel mass velocities, and fuel plate heat fluxes.

$$
\begin{aligned}
& \text { Channel } 1 \\
& \bar{T}_{i, 1}=\frac{0.5 \Delta x_{i}\left(q_{i 2} w_{m i}\right)}{c_{p i 1} G_{1} w_{c_{i l}} t_{c_{i 1}}}+T_{I_{i, 1}} \\
& \text { Channel } 7 \\
& \bar{T}_{i, 7}=\frac{0.5 \Delta x_{i}\left(q_{i 6} w_{m_{i A}}+q_{i 8} w_{m_{1 B}}\right)}{C_{p_{i 7}} G_{7} w_{c_{i 7}} t_{c_{i 7}}}+\dot{T}_{I_{i, 7}} \\
& \bar{\Gamma}_{i, 16}=\frac{0.5 \Delta x_{i}\left(q_{i 15} w_{m_{i C}}+{ }^{q_{i}}{ }^{w_{m}}\right)}{c_{p_{i 16}} G_{16}{ }^{w_{c_{i 16}}} t_{c_{i 16}}}+{ }^{\prime} r_{I_{i, 16}}
\end{aligned}
$$

\section{Channel 16}

$$
\bar{T}_{i, 22}=\frac{0.5 \Delta x_{i}\left(q_{i 21} w_{m_{i D}}\right)}{c_{p_{i 22}} G_{22} w_{c_{i 22}} t_{c_{i 22}}}+T_{I_{i, 22}}
$$

Note that in Eqs (18) and (19), it is assumed that the widths $\left(\mathrm{w}_{\mathrm{m}_{\mathrm{iB}}}\right.$ and $\left.\mathrm{w}_{\mathrm{m}_{\mathrm{iC}}}\right)$ are equal.

\section{METHOD OF COMBINING THE EQUATIONS}

The equations listed in Sections III and I.V are reduced to four general equations by substituting the coolant equations of Section IV Into the equations of Section III. These substitutions give the following matrix equation for each slab:

$$
\left|\begin{array}{llll}
s_{11} & s_{12} & s_{13} & s_{14} \\
s_{21} & s_{22} & s_{23} & s_{24} \\
s_{31} & s_{32} & s_{33} & s_{34} \\
s^{41} & s_{42} & s_{43} & s_{44}
\end{array}\right| \times\left|\begin{array}{l}
x_{A} \\
x_{B} / C \\
x_{D} \\
1 / F_{A}
\end{array}\right|=\left|\begin{array}{l}
s_{15} \\
s_{25} \\
s_{35} \\
s_{45}
\end{array}\right|
$$

In this equation, the $S$ constants are functions of dimensions, masss velocities, film coefficlents, thermal conductivity, fuel loading factors, radial neutron flux factors, and boundary temperature conditions; and the maximum temperature is located in fuel section $B$ or $C$ in the center fuel plate. The solution is found by the Crout reduction method.

\section{Vİ. DESCRIPTION OF COUE}

The code was developed using IBM-650 Symbolic Optimal Assembly Program (SOAP II) and Soap Interpretive Routine (SIR). The use of the floating point operation was the reason for the use of SIR. Typical operating times have varied from 15 to 20 minutes for nonbolling runs to runs with local boiling for a 20-slab problem, solving for elther the $\mathrm{F}_{\mathrm{A}}$ 's or $\mathrm{T}_{\mathrm{tc}}$ 's. The machine shows a "9" stop when the final slab is processed and the subassembly computations are completed. A simplified flow chart is presented in Fig. 4. 


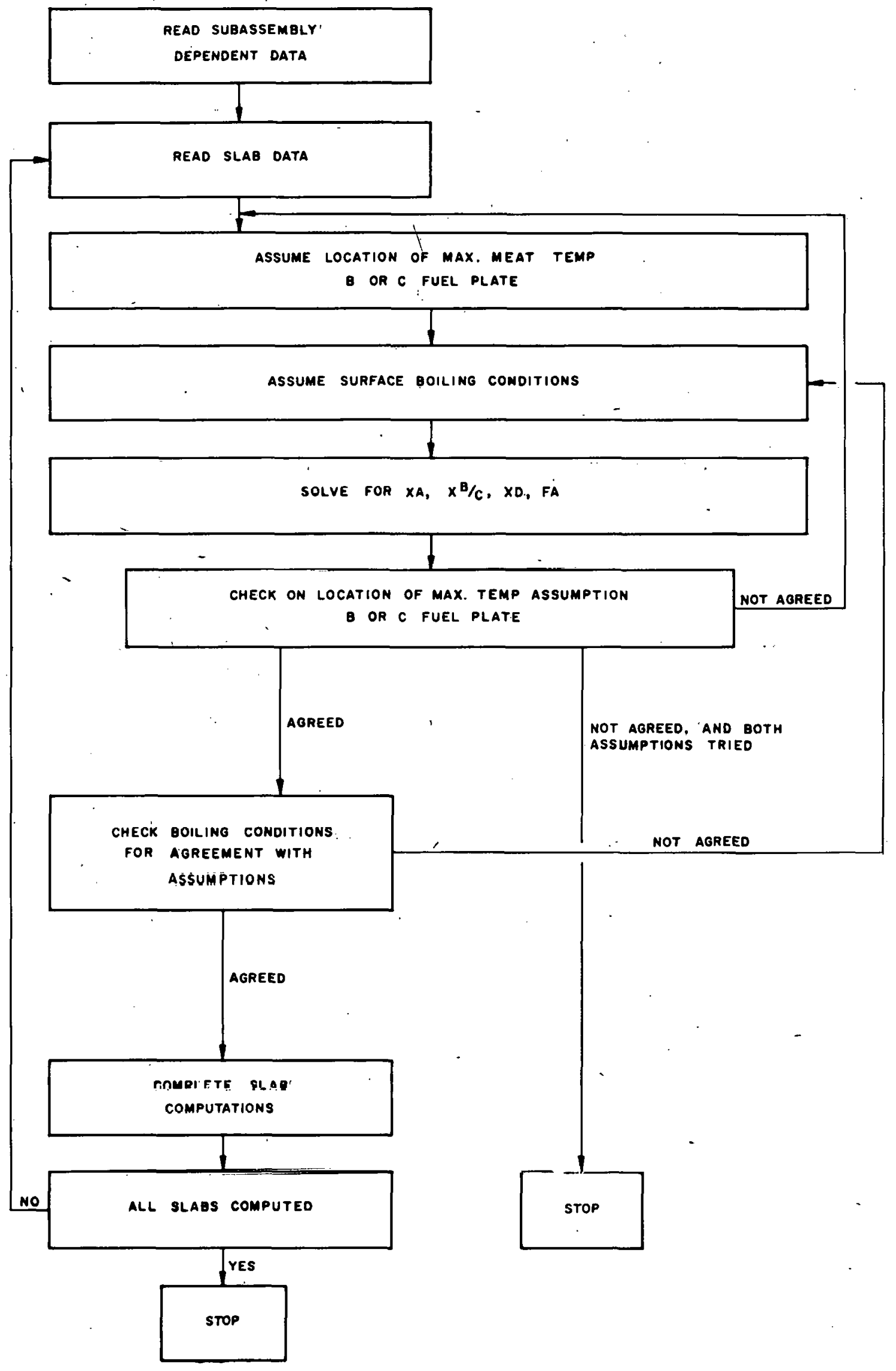

Fig. 4 Simplified Flow Chant 
A. Code Input

Table I shows the input format. The subassembly dependent data card group precedes the slab dependent data input. For example, if a 20 slab. analysis is being run, there will be 21 subgroups in the entire data deck for that run. Columns 1-5 of the first word on data cards may be used for run number identification of the data cards. All actual operating data entries are in floating point notation. For example, entering $\underline{k}$ (thermal conductivity) in word 4 of card 1 :

$\begin{array}{cl}\text { k. } & \text { Floating point k. } \\ 08.1 & 5081000000 \\ \mathrm{~T}^{*} & \text { Floating point } \mathrm{T}^{*} \\ 642.000 & 5264200000\end{array}$

Entries on card 10: $\mathrm{N}$ and Run No., are not in floating point notation. $\mathrm{N}$ denotes the number of slabs used in the analysis. For a 20-slab problem, $N$ would be entered as 0000000020 , the decimal point being at the right. The Run No. on card 10 is entered as XXXXX00000; XXXXX are the digits used for run number identification to be punched on the output of the code. The last. five digits must be punched as 00000 . This portion of the Run No. numbers the slab output with the slab number. The code modifies 00000 serially as the analysis proceeds slab-by-slab.

Input data cards must be punched as indicated in Table I, with the load hub punch in column 1 and the appropriate sign for input variables in columns $10,20,30,40,50,60,70$, and 80 , as necessary. It is not necessary to punch zeros in word, spaces where no input is indicated. An example of input listing is shown in Table I.

\section{B. Code Output}

Table II displays the output format. Word 1 contains the run identification number and slab number. Word 1 is the output resulting from Word
3 of the data input card of the subassembly dependent data goup. As indicated in Table $I$, nine cards make up the data output per slab, with a tenth card after the final slab to release the calculated average normalized neutron flux power for each of the four channels, and the average volumetric heat generation rate of the subassembly.

Word 2 of all data output' denotes the drum location from which the results are punched out. One exception is the ninth card of slab data where a series of nines is punched. Word 2 in the extra card (10th), at the end of the final slab, is the $\bar{F}_{A}$.

All data output (computations) are in floating point notation. The elghth word of card 8 on each slab output is labeled BOLC. This is the code word that describes the surface conditions under which the final calculations for that slab were performed. A BOLC appearing as 8888880000 denotes no bolling on heat transfer surfaces $2,6,8,15,17$, and 21 , respectively. A BOLC appearing as 8899880000 denotes local bolling on surface Nos. 8 and 15 . The first six digits from left to right of BOLC designate the surfaces in question. An eight signifies no boiling and nine signifies local bolling on the surface. In the case of surface 8 film boiling, 9 will be displayed in the 8-surface location.

Data output gives no direct code word for quick location of maximum fuel temperature in the $\mathrm{B}$ or $\mathrm{C}$ plate, when computing $\mathrm{F}_{\mathrm{A}}$ with $\mathrm{T}_{\text {tc }}$ input. However, when the $T_{t c}$ subroutine is used for $F_{A}$ input, giving calculations of maximum meat temperature, the $\mathrm{T}_{\text {tc }}$ calculation will be tagged with a negative sign when the maximum temperature is in the $C$ plate. When $T_{\text {to }}$ is computed, it is produced in the seventh word of the ninth card of each slab output. When $T_{\text {tc }}$ is input data for the $F_{A}$ calculation, it is listed in the eighth word of the ninth card on each slab output. $F_{A}$, whether it is input data or output data, will appear only in Word 7 of the eighth card of slab output. 
TABLE I

DATA INPUT

Subassembly Data

\begin{tabular}{|c|c|c|c|c|c|c|c|c|}
\hline Card & + Word 1 & \pm Word 2 & \pm Word 3 & \pm Word 4 & \pm Word 5 & \pm Word 6 & \pm Word 7 & \pm Word $8 \pm$ \\
\hline 1 & Run No., 04016 & $\mathrm{~V}_{\mathrm{m}}$ & $\mathrm{L}$ & $\mathrm{k}$ & $\mathrm{T}_{\mathrm{S}}$ & $\bar{q}^{\prime}, 1$ & $a_{1}$ & \\
\hline 2 & Run No., 04074 & $\mathbf{F}_{\mathbf{R}_{\mathbf{A}}}$ & $\mathbf{F}_{\mathbf{R}_{\mathbf{B}}}$ & $\mathbf{F}_{\mathrm{R}_{\mathbf{C}}}$ & $\mathbf{F}_{\mathbf{R}_{\mathbf{D}}}$ & & & \\
\hline 3 & Run No., 04114 & $\mathrm{G}_{1}$ & $\mathrm{G}_{7}$ & $\mathrm{G}_{16}$ & $\mathrm{G}_{22}$ & - & & \\
\hline 4 & Run No., 04154 & $\mathrm{H}_{\mathrm{I}}$ & $\mathrm{H}_{\mathbf{I}}$ & $\mathrm{H}_{\mathbf{I}}$ & $\mathrm{H}_{\mathbf{I}}$ & & & \\
\hline 5 & Run No., 04194 & A & B & C & $\mathrm{D}$ & & (where $C_{p}$ & $\left.=\mathrm{A}+\mathrm{BH}+\mathrm{CH}^{2}+\mathrm{DH}^{3}\right)$ \\
\hline 6 & Run No،, 04.234 & A & $\mathbf{B}$ & $\mathrm{C}$ & $\mathrm{D}$ & & (where $\mathrm{T}$ & $\left.=\mathrm{A}+\mathrm{BH}+\mathrm{CH}^{2}+\mathrm{DH}^{3}\right)$ \\
\hline 7 & Run No., 04275 & A & $\mathbf{B}$ & $\mathbf{C}$ & $\mathrm{D}$ & $\mathrm{H}_{\text {I }}$ & (where $\lambda$ & $\left.=A+B T+C T^{2}+D^{3}\right)$ \\
\hline 8 & Run No., 04324 & $\mathrm{G}_{1}^{0.8}$ & $\mathrm{G}_{7}^{0.8}$ & $\mathrm{G}_{16}^{0.8}$ & $\mathrm{G}_{22}^{0.8}$ & & & . \\
\hline 9 & Run No., 04366 & $\mathrm{~T}^{*}$ & $\mathrm{~T}^{*}$ & $\mathbf{T}^{*}$ & $\mathrm{~T}^{*}$ & $\mathrm{~T}^{*}$ & $\mathrm{~T}^{*}$ & . \\
\hline 10 & Run No., 04883 & $\mathbf{N}$ & Run No. & $\epsilon$ & & & & . \\
\hline 11 & & & & & nsfer Carc & & & \\
\hline
\end{tabular}

Slab Data (10 Cards Per Slab)

\begin{tabular}{|c|c|c|c|c|c|c|c|}
\hline 1 & Run No., 04516 & $\Delta x$ & $\mathrm{~T}_{\mathrm{tc}}{ }^{\dagger}$ & $\mathrm{w}_{\mathrm{M}_{\mathrm{A}}}$ & ${ }^{w_{M}} M_{B}$ & ${ }^{\mathrm{w}_{\mathbf{M}_{\mathbf{C}}}}$ & ${ }^{w_{M_{n}}}$ \\
\hline 2 & Run No., 04577 & b & c & $d$ & e & $\mathbf{f}$ & g \\
\hline 3 & Run No., 04644 & $l$ & $\mathrm{~m}$ & $n$ & $\mathbf{r}$ & & \\
\hline 4 & Run No., 04684 & $\mathbf{F}_{L_{A}}$ & $\mathbf{F}_{L_{\mathbf{R}}}$ & $F_{L_{0}}$ & $\mathbf{F}_{\mathrm{L}_{\mathbf{D}}}$ & & \\
\hline 5 & Run No., 04724 & $\mathrm{D}_{\mathrm{e}_{1}}^{-0.2}$ & $\mathrm{D}_{\mathrm{e}}^{-0.2}$ & $\mathrm{D}_{\mathrm{e} 16}^{-0.2}$ & $\mathrm{D}_{\mathrm{e}_{22}}^{-0.2}$ & & \\
\hline 6 & Run No., 04764 & $t_{c_{1}}$ & $t_{c_{7}}$ & $t_{c_{16}}$ & $t_{c_{23}}$ & - & \\
\hline 7 & Run No., 04804 & $w_{c_{1}}$ & $w_{c_{7}}$ & $w_{c_{16}}$ & $\mathrm{w}_{\mathrm{c}_{22}}$ & & \\
\hline 8 & Run No., 04841 & $\mathbf{F}_{\mathrm{A}}$ & & & & & . \\
\hline 9 & Run No., 07141 & a & & & & & \\
\hline & & & & & afer & : & \\
\hline
\end{tabular}

$+T_{t c}$ will be 0000000000 when computing $T_{t c}$

The following two pages of this report show actual IBM-704 input and output data sheets for a sample problem. Only the first two slabs are listed with the final slab of a 20 -slab problem.
C. Computer Operation

The console settings are as follows:

Storage entry

7019519999 
SAMPLE PROBLEM DATA INPUT

0) 100004016 0100004074 0100004114 0100004154 0100004194 0100004234 0100004275 0100004324 0100004366 2090004883 0100104516 0100104577 0100104644 0100104684 0100104724 0100104764 0100104804 0100104841 0100107141 0000109990

0100204516 0100204577 0100204644 0100204684 0100204724 0100204764 0100204804 0100204841 0100207141 0000209990
4810303571 5010000000 5614600000 5241000000 5077029200 5212325081 5020474250 5485410000 5264200000 0000000020 4882542000 4750000000 4712500000 5012279000 5023700000 4770041667 4915337500 4981995400 4712500000

4932117000 4750000000 4712500000 5012279000 5023700000 4770041667 4915337500 4982400000 4712500000
5035504050 5010000000 5611810000 5241000000 4856110000 4935110253 $4787490600-$ 5472100000 $52642 \mathrm{C} 0000$ 2009200000 0000000000 471250.0000 4712500000 4975776000 $50240<0000$ $476516666^{\circ}$ 4915337500 oũvưovivo 0000000000 4712500000 4712500000 4975776000 $5024 \cup 40000$ 4765166667 4915337500
5081000000 5010006000 5613370000 5241.000 $4612056110-$ 4715251490 4520694280 5479500000 5264200000 4310000000 4914395833 4712500000 4750000000 4975770000 5024000000 4765625000 4915295833

oujuvooüo

4914395833 4712500000 4750000000 4975776000 5024000000 4765625000 4915295833
5264198000 5010000000 5614910000 524100 4287499520 4413560528 $4214945200-$ 5486850000 5264200000 0000000000 4914645833 4750000000 4712500000 5012369000 5023880000 4768333333 4915400000

v0000000000

4914645833 4750000000 4712500000 5012369000 5023880000 47.768333333 4915400000
5790000000 ن000000000 0000000000 0000000000 $0000000000^{\circ}$ 0000000000 5241000000 0000000000 5264200000 0000000000 4914645833 4762500000 0000000000 vo00u00000 0000.000000 0000000000 U ن00000000

UUDOCOOOOOUO

4914645833 4762500000

$4762500000 \ldots 450000000$

48210000000000000000 $0000000000 \quad 0000000000$ 0000000000 0000000000 1000000000 U000000000 0000000000 5264200000 0000000000 4914354167 4762500000 0000000000 0000000000 0000000000 0000000000 0000000000 $0000000000 \quad 0000000000$ LOAD $0000000000^{\circ}$ LOAD 0000000000 LOAD LOODO000000 LOAD COO0000000. LOAD 0000000000 LOAD 0000000000 LOAD 0000000000 : LOAD $4750000000 \div$ LOAD 0000000000 LOAD 0000000000 0000000000 LOAD 0000000000 LOAD 0000000000 LOAD

LOAD

LOAD

$\angle O A D$

LOAD

LOAD

LOAD

$\angle O A D$

LOAD

LOAD

LOAD LOAD 
SAMPLE PROBLEM DATA OUTPUT

\begin{tabular}{|c|c|c|c|c|c|c|c|}
\hline 2009200001 & 0050000500 & 4725835238 & 4749615349 & $0000000000-$ & 4724529770 & 5243093376 & 5243243531 \\
\hline 2009200001 & 0000000506 & 52432.19160 & 5243092549 & 5249056492 & 5249757275 & 5251496931 & 5250833047 \\
\hline $\begin{array}{l}2009200001 \\
2009200001\end{array}$ & $\begin{array}{r}0000000512 \\
00100000518\end{array}$ & $\begin{array}{l}5249269845 \\
5523410326\end{array}$ & $\begin{array}{l}5248872421 \\
5521896641\end{array}$ & $\begin{array}{l}5256402599 \\
5522390307\end{array}$ & $\begin{array}{l}5256115442 \\
5523248741\end{array}$ & $\begin{array}{l}52642.75813 \\
5527744679\end{array}$ & $\begin{array}{l}0000000000 \\
5528174870\end{array}$ \\
\hline $2009200 \mathrm{CO} 1$ & 0000000524 & 5241177359 & 5241504568 & 5241451460 & $52411755 \equiv 8$ & 5339258540 & 5333616060 \\
\hline l 1 & 0000000530 & 5333616000 & 5337004578 & 533700457.8 & 23627 & .50108 & 501 \\
\hline 0001 & 0010000536 & 5010895723 & 5010895723 & 5811051100 & 5768198460 & 5768198400 & 100 \\
\hline 2009200001 & 0050000542 & 5243011987 & 5243011987 & 5243011987 & 5243011967 & 4981995400 & 8888880000 \\
\hline $\begin{array}{l}2009200001 \\
2009200002\end{array}$ & & $\begin{array}{l}5241088674 \\
4726356354\end{array}$ & $\begin{array}{l}5241252284 \\
4749561661\end{array}$ & & 77.9 & & 0000000000 \\
\hline 200 & 000.00 & 52442 & 524 & 52 & 52 & 525 & 783 \\
\hline 200 & $000^{\circ}$ & 523 & 029 & 52 & 525 & 526 & 00 \\
\hline 2009200002 & 0000000518 & 5524000376 & 5521530155 & 5522089416 & $55237748=5$ & 5527851413 & 5528344067 \\
\hline 200.9200002 & 0000000524 & 5241884858 & 5243457736 & 5243203683 & 5241874111 & 5339311154 & 5333744821 \\
\hline 002 & 0000000530 & 5333744821 & 5337131308 & 5337131308 & 5340276985 & 5010911173 & 5010938668 \\
\hline 2009200002 & 0000000536 & 5010934290 & 5010911019 & 5811051100 & 5768198400 & 5768198400 & 5811132100 \\
\hline 2009200002 & 0000000542 & 52431747.34 & 5243474733 & 5243426064 & $52431730 E 2$ & 4982400000 & 8888880000 \\
\hline 2009200002 & $\cos 9999999$ & 5241531108 & 5242481152 & 5242327571 & $52415248 \geq 4$ & 5265249130 & 0000000000 \\
\hline
\end{tabular}

\begin{tabular}{lllllllll}
2009200020 & 0000000500 & 4747287491 & 4749470340 & 4416763000 & 4658806841 & 5252406789 & 5263021652 \\
\hline 2009200020 & 0000000506 & 5261374687 & 5252274814 & 5256226135 & 5263273088 & 5264200000 & 5263883800 \\
2009200020 & 0000000512 & 5261870694 & 5255781158 & 5263431539 & 5262256292 & 5268820868 & 0000000000 \\
2009200020 & 0000000518 & 5516147684 & 5392626483 & 5420228488 & 5515176245 & 5510052064 & 5510232827 \\
\hline 2009200020 & 0000000524 & 5251629741 & 5266166410 & 5263506914 & 5251470353 & 5342278663 & 5336838965 \\
2009200020 & 0000000530 & 5336838965 & 5340782645 & 5340782645 & 5343282245 & 5011842061 & 5016744255 \\
2009200020 & 0000000536 & 5015479693 & 5011818653 & 5811051100 & 5765758500 & 5765535300 & 5811132100 \\
\hline 2009200020 & 0000000542 & 5252368903 & 5262997063 & 5261348619 & 5252239254 & 4930900000 & 8898880000 \\
2009200020 & 0099999999 & 5251584876 & 5266125236 & 5263466561 & 5251428325 & 5268737476 & 0000000000 \\
2009200020 & 4999999977 & 5516671957 & 5529706483 & 5530205762 & 5516428287 & 5790272090 & 0000000000.
\end{tabular}




$\begin{array}{lc}\text { Programmed } & \text { Run } \\ \text { Half cycle } & \text { Run } \\ \text { Control } & \text { Ristributor } \\ \text { Display } & \text { Stop } \\ \text { Overflow } & \text { Stop } \\ \text { Error } & \text {. S }\end{array}$

The program deck is punched to load (self loading) with IBM subroutine 1.2002. On the initial run of a series of runs, the data deck is stacked immediately behind the program deck. (See Fig. 5) The program will load and follow automatically in loading of the subassembly dependent data and first slab input data. Slab computations and slab data read-in follow until completion of the analysis.

For succeeding runs of a series, the programdeck need not be reloaded. The next complete data deck (subassembly dependent + slab data) is placed in the card reader. The next steps are to enter 0150 in the address selection, press the computer reset key, and press the program start key.

\section{Control Panel' (533 Input-Output Unit)}

The control panel for the 533 input-output unit should be wired as follows:

1) Load hub is wired out of column 1.

TABLE II

\section{DATA OUTPUT*}

Slab Data

\begin{tabular}{|c|c|c|c|c|c|c|c|c|c|}
\hline Card & \multicolumn{2}{|c|}{ Word 1} & + Word 2 & \pm Word 3 & \pm Word 4 & \pm Word 5 & \pm Word 6 & \pm Word 7 & \pm Word $8 \pm$ \\
\hline 1 & \multirow{9}{*}{$\begin{array}{c}1-8 \\
\text { Run No. }\end{array}$} & \multirow{5}{*}{$\begin{array}{c}9-10 \\
\text { Slab No. }\end{array}$} & 0000000500 & $\mathrm{x}_{\mathrm{A}}$ & $\mathrm{x}_{\mathrm{B}}$ & $x_{C}$ & $x_{D}$ & $\overline{\mathrm{T}}_{1}$ & $\overline{\mathrm{T}}_{7}$ \\
\hline 2 & & & 0000000506 & $\overline{\mathrm{T}}_{16}$ & $\overline{\mathrm{T}}_{22}$ & $\mathrm{~T}_{2}$ & $\mathrm{~T}_{6}$ & $\mathrm{~T}_{8}$ & $\mathrm{~T}_{15}$ \\
\hline 3 & & & 0000000512 & $\mathrm{~T}_{17}$ & $\mathrm{~T}_{21}$ & $\mathrm{~T}_{4}$ & $\mathrm{~T}_{19}$ & $\mathrm{~T}_{10}$ & $T_{13}$ \\
\hline 4 & & & 0000000518 & $\mathrm{q}_{2}$ & $q_{6}$ & $q_{17}$ & $q_{21}$ & $q_{8}$ & $\mathrm{q}_{15}$ \\
\hline 5 & & & 0000000524 & ${ }^{\mathrm{H}} \mathrm{O}_{1}$ & $\mathrm{H}_{7}$ & $\mathrm{H}_{\mathrm{O}_{16}}$ & $\mathrm{H}_{\mathrm{O}_{22}}$ & $\mathrm{~h}_{2}$ & $h_{6}$ \\
\hline 6 & & 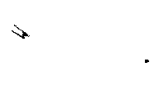 & 0000000530 & $\mathrm{~h}_{8}$ & $h_{15}$ & $\mathrm{~h}_{17}$ & $\mathrm{~h}_{21}$ & $\mathrm{C}_{\mathrm{P}_{1}}$ & $\mathrm{C}_{\mathrm{p}_{7}}$ \\
\hline 7 & & & 0000000536 & $\mathrm{c}_{\mathrm{p}_{16}}$ & $\mathrm{C}_{\mathrm{p}_{22}}$ & . & & & \\
\hline 8 & & & 0000000542 & $\mathrm{~T}_{\mathrm{I}_{1}}$ & $\mathrm{~T}_{\mathrm{I}_{7}}$ & $\mathrm{~T}_{\mathrm{I}_{16}}$ & $\mathrm{~T}_{\mathrm{I}_{22}}$ & $\mathbf{F}_{\mathrm{A}}$ & BOLC \\
\hline \multirow[t]{3}{*}{9} & & & 0099999999 & $\overline{\mathrm{H}}_{1}$ & $\overline{\mathrm{H}}_{7}$ & $\overline{\mathrm{H}}_{16}$ & $\overline{\mathrm{H}}_{22}$ & $\mathrm{~T}_{\text {tc }}$ output & $\mathrm{T}_{\text {tc }}$ input \\
\hline & ' & & & \multicolumn{3}{|c|}{ Subassembly Data (10th Card) } & & & \\
\hline & $\begin{array}{c}1-8 \\
\text { Run No. }\end{array}$ & $\begin{array}{l}9-10 \\
\text { No. of } \\
\text { last } \\
\text { slab }\end{array}$ & $\overline{\mathbf{F}}_{\mathrm{A}}$ & $P_{1 \text { calc }}$ & $P_{7 \text { calc }}$ & $P_{16 \text { calc }}$ & $\mathrm{P}_{22 \text { calc }}$ & $\bar{q}{ }_{\text {callc }}^{\prime \prime \prime}$ & $\mathrm{T}_{\text {tc }}$ inpüt \\
\hline
\end{tabular}

* Slab data output consists of 9 cards per slab.

Additional card (subassembly data) with the last slab. 
2) Eight ten-digit words input from READ C.

3) Punch eight ten-digit words from PUNCH C.

4) Read and punch signs over units.

D. Code Subroutines

$T_{\text {tc }}$ Computation Subroutine - The code is constructed basically for $F_{A}$ computation with $T_{\text {tc }}$ (thick plate center temperature) input. For $T_{\text {tc }}$ computation with $F_{A}$ input, a subroutine deck insertion is required for the basic program deck. This deck is inserted immediately before the final 13 cards of the main program deck.

Film Boiling Subroutine - This is inserted immediately before the final 13 cards of the main program deck. When a condition of film bolling is known or assumed to exist in a test run, the routine will solve for the actual temperature associated with $\mathrm{T}_{\mathbf{8}}^{*}$

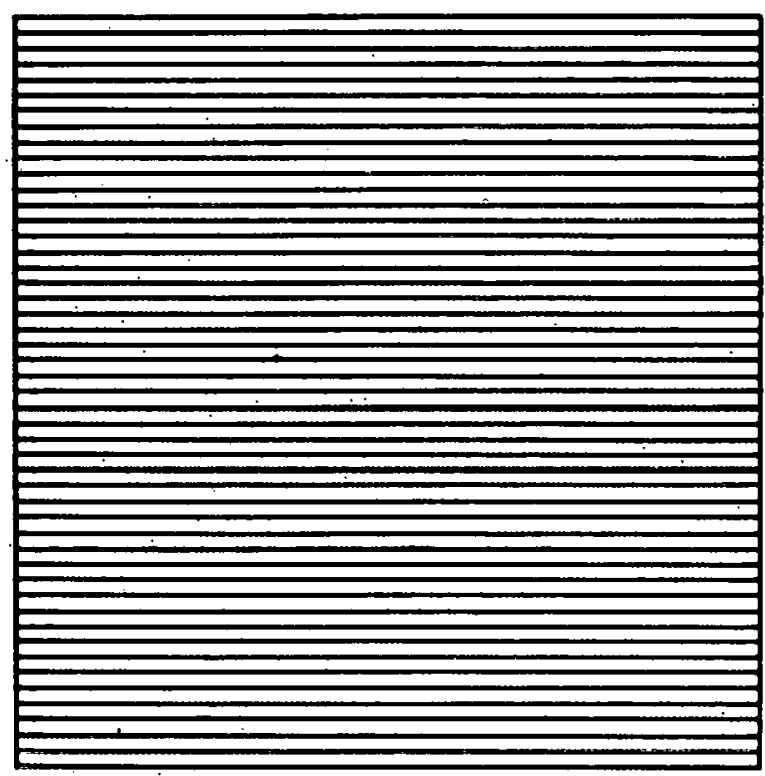
boiling. (refer to Table I).

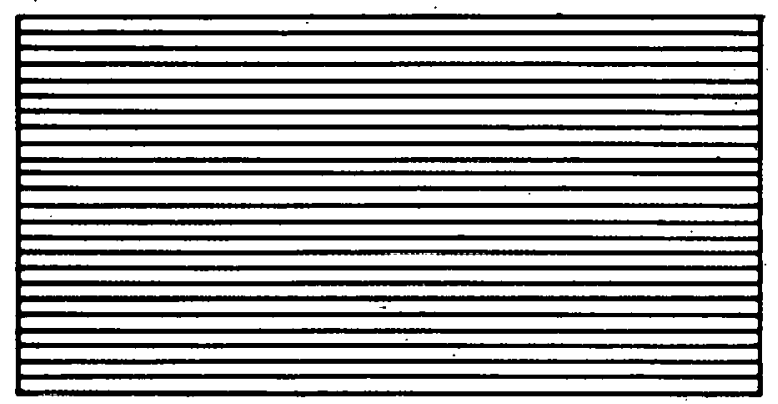

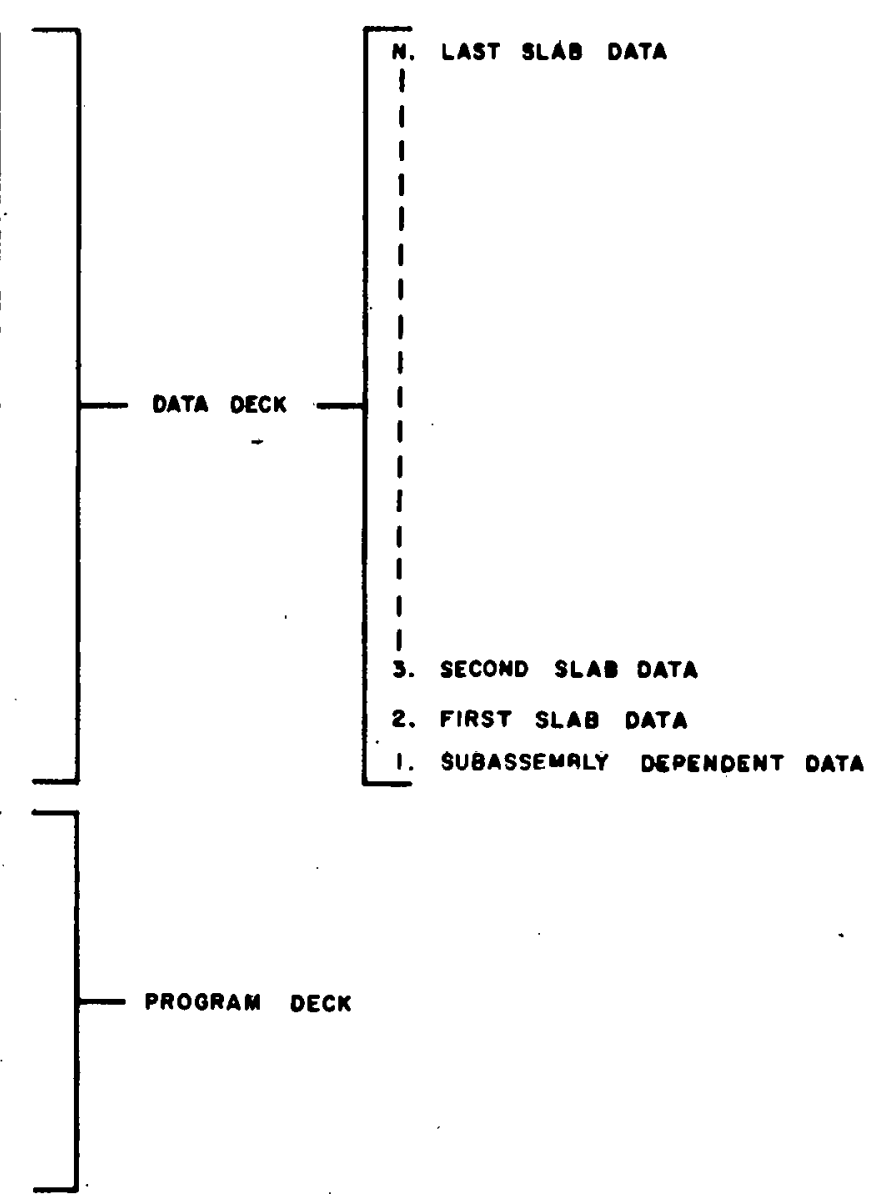

The thermocouple $T_{\text {tc }}$ input of the run must be tagged for each slab to designate the slab or slabs where film boiling will occur. This is accomplished by punching an " 8 " in the units position of each $\mathrm{T}_{\text {tc }}$ input for the slabs where film bolling will occur. All $\mathrm{T}_{\text {tc }}$ inputs for the other slabs must be punched with a " 9 " in the units position. For instance, a $\mathrm{T}_{\text {tc }}$ input of 5287686588 denotes film boiling in the slab, while 5287686589 would denote no film

This subroutine is used when computing $\mathbf{F}_{A}$ with $\mathrm{T}_{\text {tc }}$ input only. On slabs where film boiling occurs, $F_{A}$ must be input in the regular manner

\section{APPENDIX A: A NOTE ON THE ASSUMPTION OF SEPARABILITY OF VARIABLES}

The assumption was made in the analysis, for calculational purposes, that the axial and radial

SUBASSEMALY DEPENDENT DATA

Fig. 5 Card Loading for Iniflal Run 
neutron fluxes were separable, i.e., the axial neutron flux was the same for each fuel plate at any elevation, and the radial neutron factor was a constant in a given fuel plate but could be different for different fuel plates. Also, the assumption was made that the local volumetric heat generation rate could be expressed as

$$
q^{\prime \prime \prime}=\bar{q}^{\prime \prime \prime} F_{L_{i u}} F_{A_{i}} F_{R_{u}}
$$

Integrating both sides of this equation with respect to the differential volume gives the total heat output as

$$
Q=\int_{0}^{V} \bar{q}^{\prime \prime} F_{L_{i u}} F_{A_{i}} F_{R_{u}} d V
$$

Dividing both sides of the equation by the total volume of the meat $\mathrm{V}_{\mathrm{m}}$, and taking the average volumetric heat generation rate outside of the integral sign gives

$\frac{Q}{V_{m}}=\bar{q}^{\prime \prime \prime}=\left(\frac{\bar{q}^{\prime \prime \prime}}{V_{m}}\right) \int_{0}^{V_{m}} \quad F_{L_{i u}} F_{A_{i}} F_{R_{u}} d V$.

Reducing the equation gives

$$
1=\left(\frac{1}{V_{m}}\right) \int_{0}^{V_{m}} F_{L_{i u}} F_{A_{i}} F_{R_{u}} d V
$$

It is apparent that this equation agrees with the assumption of separability of variables if the local product of the factors is equal to one, or if the integration over the volume equals the total volume. Where the variables are assumed separable and each variable has an average of one, as used in this analysis, complete compliance with the given equation would be rare. Therefore, when a problem is calculated and the loading and neutron factors each has an average of one, deviation can be expected between the input and output average volumetric heat generation rate. Inspection of several sets of data indicates that this deviation has a maximum of three-tenths of a percent and is, therefore, quite small when compared to the known accuracy of most data.

\section{ACKNOWLEDGEMENTS}

The authors wish to express their appreciation for the contributions of A. V. Grimaud of the MTR Computing Facility, Phillips Petroleum Company, $\mathrm{AEC}$, for his invaluable aid in programming the problem, and J. Newhard, Northwestern University, for his computational assistance.

\section{REFERENCES}

1. W. H. Jens and P. A. Lottes, "Analysis of Heat Transfer, Burnout, Pressure Drop, and Density Data for High-Pressure Water," ANL-4627 (May 1, 1951).

2. W. H. McAdams, Heat Transmission, 3rd Ed., (New York: McGraw-Hill, 1954).

3. P. J. Schneider, Conduction Heat Transfer, (Cambridge, Mass. Addison-Wesley Publishing Company, Inc., 1955). 